Article

\title{
Biochar Type, Ratio, and Nutrient Levels in Growing Media Affects Seedling Production and Plant Performance
}

\author{
Antonios Chrysargyris ${ }^{1}$, Munoo Prasad ${ }^{1,2,3}$, Anna Kavanagh ${ }^{3}$ and Nikos Tzortzakis ${ }^{1, *(1)}$ \\ 1 Department of Agricultural Sciences, Biotechnology and Food Science, Cyprus University of Technology, \\ Lemesos 3603, Cyprus; a.chrysargyris@cut.ac.cy (A.C.); Munoo.Prasad@cut.ac.cy (M.P.) \\ 2 Compost/AD Research \& Advisory (IE/CY), Naas, W91TYH3 Kildare, Ireland \\ 3 Bord na Mona Horticulture Ltd. Research Centre, Main Street, Newbridge, W12XR59 Kildare, Ireland; \\ annamarykavanagh@gmail.com \\ * Correspondence: nikolaos.tzortzakis@cut.ac.cy; Tel.: +357-2500-2280
}

Received: 21 July 2020; Accepted: 16 September 2020; Published: 18 September 2020

\begin{abstract}
Biochar can be used as an alternative component in growing media, positively affecting plant growth/yield, but also media properties. In the present study, two commercial grade biochars (BFW-forest wood; and BTS-fresh wood screening), mainly wood-based materials, were used at $7.5 \%$ and $15 \%(v / v)$, adding nutrient in two levels (100\% and $150 \%$ standard fertilizer level-Fert). Biochar affected growing media properties, with increases on $\mathrm{pH}$ and changes on the nutrient content levels. Biochar BFW enhanced the emergence of seeds in comparison to the control. Increased fertilizer levels benefited plant yield in BFW and BTS at 7.5\%, but not at 15\%. Leaf stomatal conductance was reduced at $150 \%$ fertilized biochars (BFW + Fert and BTS + Fert) at $7.5 \%$, while total chlorophylls increased at BTS + Fert at $7.5 \%$ and $15 \%$. The addition of biochars decreased the antioxidant activity in the plant. Lipid peroxidation in lettuce was increased in most cases with the presence of biochars (BFW, BTS) and $150 \%$ fertilization, activating antioxidant (superoxide oxidase and peroxidase) enzymatic metabolisms. The addition of Biochars in the growing media increased the content of nutrients in seedlings, as plants could absorb more available nutrients. Biochar of beech, spruce, and pine species (BFW) at 7.5\% was more promising for substituting peat to produce lettuce seedlings. However, examining different species (tomato, leek, impatiens, and geranium) with BFW at $7.5 \%$, the results were not common, and each species needs to be evaluated further.
\end{abstract}

Keywords: biochar; peat; growth; lettuce; emergence; nursery production; container; extractable nutrients; plant nutrient content

\section{Introduction}

Biochar is produced with dry pyrolysis of the organic matter, in which plant or animal-based organic materials are subjected to high temperatures $\left(450\right.$ to $\left.600^{\circ} \mathrm{C}\right)$, under hypoxia or anoxia environment [1,2], whereas lower temperature $\left(300^{\circ} \mathrm{C}\right)$ have been reported for biochar production [3]. The initial organic material for biochar production is mainly wastes coming from intensive sectors, such as forest residues and wood industries, agriculture and food, and greatly contribute to the environmental management and recycling, reducing the greenhouse gas (GHG) emission and increasing carbon sequestration [4-7]. The use of biochar in the agriculture sector as an alternative container growing media adds value to the bioenergy business process [8]. Moreover, biochar can alleviate salinity stress in crops with important environmental, agriculture, and economic benefit [9]. Biochar has demonstrated the potential for inclusion in growing media, together with different materials such as peat $[3,10]$, compost $[8,11]$, coir [3] and vermicompost [12]. 
Nowadays, there is a great deal of interest in the use of biochar as a peat replacement as evidenced by increasing scientific publications. This is supported by research and review articles [13-18]. The main objectives of this research have been to investigate if biochar could replace either totally or partly peat. Dilution rates as high as 50 to $75 \%$ mixed with peat or even at $100 \%$ have been tried with mixed results [19-21]. The objective of these peat replacement trials was often to show that at these high rates, biochar/peat mixtures performed as good as peat mostly as evidenced by plant height, fresh and dry weight $[21,22]$. Increased biochar ratio had conflicting impacts, either by increasing plant growth (higher biomass and height) i.e., 60-80\% conifer wood biochar in Euphorbia $\times$ lomi [23] or by suppressing plant growth i.e., 60-100\% pinewood biochar in poinsettia (Euphorbia pulcherrima L.) [20] and $80-100 \%$ pinewood biochar in tomato (Solanum lycopersicum L.) and basil (Ocimum basilicum L.) [24]. However, the researchers did not always take into consideration the economic viability of the use of biochar as a peat replacement. At the cost from $\$ 67-177$ per $\mathrm{m}^{3}$ (bulk density of $0.3 \mathrm{~kg} \mathrm{~L}^{-1}$ ) of biochar

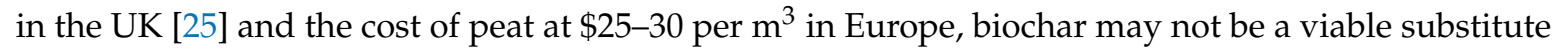
as a peat replacement at high ratios, unless the mixtures of peat and biochar would outperform $100 \%$ professional grade peat. Handling and incorporation of biochar as a growing media constituent would also need to be considered. There are certain extraneous advantages in mixing biochar with peat due to its properties other than based on saving on peat and crop performance. For instance, the use of biochar would lead to reduction or elimination of certain inputs such as lime and certain fertilizers, e.g., potassium $[2,10,26]$ and thus lead to savings. Use of biochar could get carbon credits, a monetary advantage, and improve the efficiency of nutrient inputs through reduced leakage of nutrients [27] to the environment, an additional savings.

There are reports that biochar may have bio-stimulant properties due to its ability to change gene expression (i.e., transcription of auxin- and brassinosteroid-related genes in Arabidopsis) of the plants and the presence of gibberellic acid in biochar and these could lead to changes the morphological-physiological aspects of the plants [28,29]. Prendergast-Miller et al. [30] showed that biochar is attracting roots, resulting in its partitioning between bulk and rhizosphere soil and thus, biochar directly regulates the acquisition of plant root nutrients as a source of nutrients. Fewer studies investigated the impacts of biochar on different plant growth characteristics that affect yield, such as seed germination and the architecture of shoots or roots [1,30,31]. A few papers have applied low rates of biochar at $1-15 \%$ to peat $[1,16,32,33]$ and have found a positive response, not only on fresh and dry weight, but also morphological and physiological changes [28,29,34]. We also know from previous publications that all biochars do not behave in a similar way ("not all biochars are made equal") and crop response depends on crop species. Therefore, biochar properties are significantly affected by feedstock, temperature, and residence time. Thus, even with the same feedstock, the properties such as surface area and pore volume will vary with temperature [35]. In addition, the application of biochar and the effects of the production of greenhouse seedlings or subsequent growth of seedlings have been less reported $[34,36]$. In the recent years, the field of seedling and potting horticultural plants has been significantly increased [37-39]. Since biochar from different resources has different characteristics due to potential phytotoxicity, some may have adverse effects on plant growth. Phytotoxicity evaluation is important to a successful soil/soilless amendment with bioenergy by-products such as biochar [40], and seed germination testing is a reliable procedure for biochar phytotoxicity tests.

Biochar presence in soil can modify the abundance, activity, and community structure of microorganisms in the soil. Adding cotton straw biochar (i.e., $4.5 \mathrm{t} \mathrm{ha}^{-1}$ ) in desert soil increased microbial respiration and carbon and nitrogen biomass with increases of activity of key enzymes involved in carbon and nitrogen transformation [41]. Gomez et al. [42] reported that low rates of biochars increased the microbial abundance with Gram-negative bacteria dominating the microbial community; however, high biochar rates (i.e., $49 \mathrm{t} \mathrm{ha}^{-1}$ ) inhibited microbial activity and reduced extractable phospholipid fatty acid [43]. Therefore, biochar amendment impact is greatly depending on biochar properties and soil characteristics and the possible biochar-microorganism interaction 
mechanisms include toxicity and emission of volatile organic compounds acting directly on soil microorganisms or indirectly by changing soil properties and enzymatic activities [44].

Biochar application can reduce $\mathrm{N}$ and $\mathrm{P}$ uptake from the plants and additional fertilization may be required for successful plant growth [34]. Moreover, the effects of biochar on plant growth may differ with plant species since different plants may have different growing conditions or different tolerances to certain stresses. The present study was conducted with two biochars from different raw materials mixed with professional grade peat at low rates (a) to assess the impact of biochar substitution in peat on extractable nutrients and phytotoxicity for lettuce (Lactuca sativa L.) seed emergence, (b) to assess the impact of biochar on lettuce plant growth, physiology, and nutrient content, (c) to evaluate the fertilizer dose and biochar ratio in peat on plant metabolism and nutrient content, and (d) based on the optimum biochar applications on lettuce, four more plant species were examined for their performance on biochar application.

\section{Materials and Methods}

\subsection{Biochars and Plant Material}

In the present study, lettuce (Lactuca sativa L. var. Nogal; Hazera, Israel) seeds were used for seedling production. Two commercial grade biochars of the following feedstocks were used: forest wood, e.g., beech, spruce, and pine from Germany (BFW), and fresh wood screenings $(0-20 \mathrm{~mm})$ from tree and shrub cuttings mainly from urban areas and farms (fruit trees, hedges, hedgerow management) from Switzerland (BTS). Biochars were produced using either the Pyreg equipment (Verora, Edlibach, Switzerland) for Biochar BTS at 500-600 ${ }^{\circ} \mathrm{C}$, or Schottdorf-Meiler equipment (Carbon Terra, Wallerstein, Germany) for Biochar BFW at $700{ }^{\circ} \mathrm{C}$ with retention time of $15-30 \mathrm{~min}$. Nonetheless, due to business sensitivity, additional data on the specifics of Biochar production are not known. A high-quality industry standard professional grade $\mathrm{H}_{4}-\mathrm{H}_{5}$ on von Post scale fertilized/limed peat (P) from Bord na Mona (Newbridge, Ireland) was used as a reference (control) and as basic substrate to which the biochar was added. The selected biochars had roughly the same particle size to eliminate/reduce the effect on physical properties as far as possible. Biochars were evaluated for their chemical properties [38], as for pH (EN 13,037 2002) [45], Electrical Conductivity (EC) in water extract at 1:5 (v/v) ratio (EN 13,038 2002) [46], and barium chloride/DTPA (CAT) extractable (1:5 v/v) potassium $(\mathrm{K})$ and phosphorus $(\mathrm{P})$, ammonium $\left(\mathrm{NH}_{4}-\mathrm{N}\right)$, nitrate $\left(\mathrm{NO}_{3}-\mathrm{N}\right)$, and total extractable $\mathrm{N}$ $\left(\mathrm{NH}_{4}-\mathrm{N}+\mathrm{NO}_{3}-\mathrm{N}\right)(\mathrm{EN} 13651-2002)$ [47]. Barium Chloride was substituted for Calcium Chloride at the same concentration, in order to determine $\mathrm{Ca}$ in the extract. The surface area determined with the Brunauer, Emmett, and Teller method [48]. Peat physicochemical characteristics have been reported previously [10]. Physicochemical properties of biochars BWF and BTS and peat are presented in Table 1.

Table 1. Physicochemical properties of biochars and peat.

\begin{tabular}{|c|c|c|c|}
\hline & Peat & BWF & BTS \\
\hline $\mathrm{pH}$ & 3.13 & 9.57 & 9.55 \\
\hline $\mathrm{EC}\left(\mathrm{mS} \mathrm{cm}^{-1}\right)$ & 0.034 & 0.613 & 0.410 \\
\hline $\mathrm{NH}_{4}-\mathrm{N}\left(\mathrm{mg} \mathrm{L}^{-1}\right)$ & 17.0 & $<1.0$ & $<1.0$ \\
\hline $\mathrm{NO}_{3}-\mathrm{N}\left(\mathrm{mg} \mathrm{L}^{-1}\right)$ & 3.0 & $<1.0$ & $<1.0$ \\
\hline $\mathrm{K}\left(\mathrm{mg} \mathrm{L}^{-1}\right)$ & 8.0 & 1087.0 & 745.0 \\
\hline$P\left(\mathrm{mg} \mathrm{L}^{-1}\right)$ & 6.0 & 2.0 & 3.0 \\
\hline Oxygen Uptake Rate (mmol $\mathrm{O}_{2} \mathrm{~kg}^{-1}$ organic matter per hour) & 5.5 & 2.3 & 4.3 \\
\hline Particle size of $<1 \mathrm{~mm}(\%)$ & 51.0 & 63.9 & 60.5 \\
\hline Particle size of $1-5 \mathrm{~mm}(\%)$ & 46.0 & 35.6 & 37.0 \\
\hline Particle size of $>5 \mathrm{~mm} \mathrm{( \% )}$ & 3.0 & $<1.0$ & 3.0 \\
\hline Surface area $\left(\mathrm{m}^{2} \mathrm{~g}^{-1}\right)$ & 2.4 & 243.2 & 62.3 \\
\hline
\end{tabular}




\subsection{Preparation of Growing Media}

In the present study, two individual experiments were carried out. In the first experiment (Exp. I), the biochars (BFW, BTS) mixed into the peat into two ratios $(7.5 \%$ and $15 \% \mathrm{v} / \mathrm{v})$ and took the mixtures to $\mathrm{N}$, P, and K levels (with standard fertilizers; $100 \%$ ) to $170 \mathrm{mg} \mathrm{N} \mathrm{L}^{-1}$ as ammonium nitrate, $70 \mathrm{mg} \mathrm{P} \mathrm{L}^{-1}$ as triple superphosphate and $100 \mathrm{mg} \mathrm{K} \mathrm{L}^{-1}$ as potassium sulphate respectively for the peat-biochar mixtures and limed peat (dolomitic lime at $4 \mathrm{~g} \mathrm{~L}^{-1}$ ) plus addition of standard level of trace elements to all treatments (Table S1). The CAT extractable N, P, and $\mathrm{K}$ that derived from the biochars were considered and the levels of fertilizers have been adjusted appropriately. In most cases, there were nearly insignificant amounts of $\mathrm{N}$, some $\mathrm{P}$, and excess of $\mathrm{K}$. No $\mathrm{K}$ has been added into the mixture of $100 \%$ fertilization in the case of $\mathrm{K}$ excess (K greater than that applied in standard fertilizer i.e., $>100 \mathrm{mg} \mathrm{K} \mathrm{L}^{-1}$ ). The application of additional fertilizers (150\%) named as " Fert" was also examined. Therefore, the BFW and BTS biochars were selected at the rates of $0 \%, 7.5 \%$, and $15 \%$ to the peat under $100 \%$ standard rate ( $\mathrm{N}$ of $170 \mathrm{mg} \mathrm{L}^{-1}$, P of $70 \mathrm{mg} \mathrm{L}^{-1}$, and $\mathrm{K}$ of $100 \mathrm{mg} \mathrm{L}^{-1}$ ) or $150 \%$ standard rate ( $\mathrm{N}$ of $255 \mathrm{mg} \mathrm{L}^{-1}$, $\mathrm{P}$ of $105 \mathrm{mg} \mathrm{L}^{-1}$, and $\mathrm{K}$ of $150 \mathrm{mg} \mathrm{L}^{-1}$ ) of fertilizers, resulting in 10 mixtures (treatments) including control (100\% peat). The examined treatments, their interactions, and chemical analysis for growing media are presented in Tables 2 and 3.

Table 2. Effects of different biochar types (BFW, BTS) and ratio $(7.5 \%, 15 \%)$ and mineral doses (with standard or with additional Fertilizers-F) on lettuce plant growth, physiology, and nutrient content.

\begin{tabular}{|c|c|c|c|c|c|c|c|}
\hline & Biochar Type (T) & Biochar Ratio (R) & Fertilizers (F) & $\mathbf{T} \times \mathbf{R}$ & $\mathbf{T} \times \mathbf{F}$ & $\mathbf{R} \times \mathbf{F}$ & $\mathbf{T} \times \mathbf{R} \times \mathbf{F}$ \\
\hline \multicolumn{8}{|l|}{ Growing media } \\
\hline $\mathrm{EC}\left(\mathrm{mS} \mathrm{cm}^{-1}\right)$ & $* * *$ & $* * *$ & $* * *$ & * & $* *$ & ns & ns \\
\hline pH & $* * *$ & $\mathrm{~ns}$ & ns & $* * *$ & ns & ns & $*$ \\
\hline Organic matter (\%) & *** & *** & * & *** & ns & ns & ns \\
\hline Organic C $(\%)$ & $* * *$ & $* * *$ & * & $* * *$ & ns & ns & ns \\
\hline $\mathrm{N}\left(\mathrm{mg} \mathrm{L}^{-1}\right)$ & ** & $* * *$ & $* * *$ & $* * *$ & ns & ns & ns \\
\hline $\mathrm{K}\left(\mathrm{mg} \mathrm{L}^{-1}\right)$ & $* * *$ & $* * *$ & $* * *$ & $* * *$ & ns & $* *$ & $* *$ \\
\hline $\mathrm{P}\left(\mathrm{mg} \mathrm{L}^{-1}\right)$ & ns & $* *$ & $* * *$ & * & $* *$ & ns & $* * *$ \\
\hline $\mathrm{Ca}\left(\mathrm{mg} \mathrm{L}^{-1}\right)$ & $* * *$ & ns & $*$ & ns & ns & ns & $*$ \\
\hline $\mathrm{Mg}\left(\mathrm{mg} \mathrm{L}^{-1}\right)$ & ns & $* * *$ & ns & $*$ & ns & ns & ns \\
\hline $\mathrm{Na}\left(\mathrm{mg} \mathrm{L}^{-1}\right)$ & $* * *$ & $* * *$ & ns & $* * *$ & ns & ns & ns \\
\hline $\mathrm{SO}_{4}-\mathrm{S}\left(\mathrm{mg} \mathrm{L}^{-1}\right)$ & $* * *$ & $* * *$ & $* * *$ & $* * *$ & $* * *$ & $* * *$ & $* * *$ \\
\hline $\mathrm{Fe}\left(\mathrm{mg} \mathrm{L}^{-1}\right)$ & $* * *$ & $* * *$ & * & $* * *$ & $* * *$ & $* * *$ & $* * *$ \\
\hline $\mathrm{Cu}\left(\mathrm{mg} \mathrm{L}^{1}\right)$ & $* * *$ & ns & $* * *$ & ns & $* * *$ & $* * *$ & $* * *$ \\
\hline $\mathrm{Zn}\left(\mathrm{mg} \mathrm{L}^{-1}\right)$ & $* * *$ & $* * *$ & $\mathrm{~ns}$ & $* * *$ & $\mathrm{~ns}$ & $\mathrm{~ns}$ & $\mathrm{~ns}$ \\
\hline $\operatorname{Mn}\left(\mathrm{mg} \mathrm{L}^{-1}\right)$ & $* * *$ & $* * *$ & ns & $* * *$ & ns & ns & ns \\
\hline $\mathrm{B}\left(\mathrm{mg} \mathrm{L}^{-1}\right)$ & $* * *$ & $* *$ & ns & ** & ns & ns & ns \\
\hline \multicolumn{8}{|l|}{ Lettuce plant } \\
\hline Plant height $(\mathrm{cm})$ & * & ns & $* * *$ & * & ns & ** & $* *$ \\
\hline Leaf Number & ns & ns & $* *$ & ns & ns & ns & * \\
\hline Chlorophyll fluorescence (Fv/Fm) & **** & $* * *$ & ns & ns & $* *$ & ns & $* * *$ \\
\hline Stomatal conductance $\left(\mathrm{cm} \mathrm{s}^{-1}\right)$ & ns & ns & ns & $*$ & * & $* *$ & ns \\
\hline Fresh weight $(\mathrm{g})$ & ns & ns & $* * *$ & ns & ns & ns & ns \\
\hline Dry weight $(\mathrm{g})$ & ns & ns & *** & ns & ns & * & ns \\
\hline Chlorophyll a (mg g $\left.{ }^{-1} \mathrm{Fw}\right)$ & * & ns & * & $*$ & $*$ & ns & ns \\
\hline Chlorophyll b (mg g $\left.{ }^{-1} \mathrm{Fw}\right)$ & * & ns & $* *$ & * & * & ns & ns \\
\hline Total Chlorophylls $\left(\mathrm{mg} \mathrm{g}^{-1} \mathrm{Fw}\right)$ & * & ns & * & * & * & ns & ns \\
\hline Total phenolics (mg GAE g $\left.{ }^{-1} \mathrm{Fw}\right)$ & ns & ns & ns & * & ns & ns & ns \\
\hline FRAP $\left(m g\right.$ trolox $\left.g^{-1} \mathrm{Fw}\right)$ & * & ns & ns & $* *$ & ns & ns & ns \\
\hline DPPH (mg trolox g $\left.{ }^{-1} \mathrm{Fw}\right)$ & ns & ns & ns & * & ns & ns & ns \\
\hline $\mathrm{H}_{2} \mathrm{O}_{2}\left(\mathrm{nmol} \mathrm{g}^{-1} \mathrm{Fw}\right)$ & ns & ns & $* * *$ & $* * *$ & $* * *$ & ns & ns \\
\hline MDA (nmol g $\left.{ }^{-1} \mathrm{Fw}\right)$ & $* * *$ & $* * *$ & $* *$ & $* * *$ & $* * *$ & $* * *$ & $* *$ \\
\hline SOD (units $\mathrm{mg}^{-1}$ protein) & * & ns & ns & ns & ns & ns & * \\
\hline CAT (units $\mathrm{mg}^{-1}$ protein) & ns & $* * *$ & $*$ & *** & $* *$ & $* *$ & * \\
\hline POD (units $\mathrm{mg}^{-1}$ protein) & ns & $* * *$ & $* * *$ & ns & ns & ns & ns \\
\hline $\mathrm{N}\left(\mathrm{g} \mathrm{kg}^{-1}\right)$ & $* * *$ & $* * *$ & $* *$ & ns & $* * *$ & $* * *$ & $* * *$ \\
\hline $\mathrm{K}\left(\mathrm{g} \mathrm{kg}^{-1}\right)$ & $* * *$ & $* * *$ & ns & $* * *$ & $* * *$ & $* * *$ & ** \\
\hline $\mathrm{P}\left(\mathrm{g} \mathrm{kg}^{-1}\right)$ & $* * *$ & ns & $* * *$ & $* * *$ & $* * *$ & $* * *$ & $* * *$ \\
\hline $\mathrm{Ca}\left(\mathrm{g} \mathrm{kg}^{-1}\right)$ & $* * *$ & *** & $* * *$ & ns & ns & $* *$ & ns \\
\hline $\mathrm{Mg}\left(\mathrm{g} \mathrm{kg}^{-1}\right)$ & $* * *$ & $* * *$ & $* * *$ & * & ns & $* *$ & ns \\
\hline $\mathrm{Na}\left(\mathrm{g} \mathrm{kg}^{-1}\right)$ & $* * *$ & ns & $* * *$ & $* * *$ & $* * *$ & $* * *$ & ns \\
\hline $\mathrm{Fe}\left(\mathrm{mg} \mathrm{kg}^{-1}\right)$ & ns & ns & $*$ & $*$ & ns & ns & ns \\
\hline $\mathrm{Cu}\left(\mathrm{mg} \mathrm{kg}^{-1}\right)$ & $* * *$ & $* * *$ & $* * *$ & $* * *$ & $\begin{array}{c}\text { ns } \\
*\end{array}$ & $\begin{array}{c}\mathrm{ns} \\
*\end{array}$ & ns \\
\hline $\mathrm{Zn}\left(\mathrm{mg} \mathrm{kg}^{-1}\right)$ & $* * *$ & $* * *$ & * & $* * *$ & $* * *$ & $* * *$ & $* * *$ \\
\hline
\end{tabular}

${ }^{*}, * * * *$ Significant difference at $p \leq 5 \%, 1 \%$, and $0.1 \%$ following three-way ANOVA. ns: non-significant. 
Table 3. Effects of peat (P) with different biochar types (BFW, BTS) and ratio (7.5\%, 15\%) and mineral doses (with standard or with additional Fertilizers-Fert.) on substrate minerals content.

\begin{tabular}{|c|c|c|c|c|c|c|c|c|c|c|}
\hline & $\mathbf{P}$ & P + Fert & BFW 7.5\% & BFW + Fert 7.5\% & BFW 15\% & BFW + Fert 15\% & BTS $7.5 \%$ & BTS + Fert 7.5\% & BTS 15\% & BTS + Fert $15 \%$ \\
\hline $\mathrm{EC}\left(\mu \mathrm{Scm}^{-1}\right)$ & (5) & & 32 & & 5 & 23 & $\begin{array}{r}318.90 \pm 15.41 \mathrm{~d} \\
486+0.06 \mathrm{c}\end{array}$ & $\mathrm{b}$ & $\begin{array}{c}252.66 \pm 11.16 \mathrm{e} \\
4.57+0.02 \mathrm{~d}\end{array}$ & $3 d$ \\
\hline & $\begin{array}{r}4.79 \pm 0.01 \mathrm{c} \\
96.32 \pm 0.18 \mathrm{a}\end{array}$ & $4.89 \pm 0.05 c$ & $5.08 \pm 0.06 \mathrm{~b}$ & $4.86 \pm 0.6 \mathrm{c}$ & $5.42 \pm 0.03 a$ & $5.41 \pm 0.05$ & $4.86 \pm 0.06 \mathrm{c}$ & T. & $4.07 \pm 0.6$ & \\
\hline Organic matter $(\%)$ & $96.32 \pm 0.18 \mathrm{a}$ & $94.84 \pm 0.02 \mathrm{c}$ & $95.71 \pm 0.11 \mathrm{~b}$ & $95.76 \pm 0.17 \mathrm{ab}$ & $95.57 \pm 0.10 \mathrm{~b}$ & $96.01 \pm 0.02 \mathrm{ab}$ & $94.74 \pm 0.09 c$ & $94.76 \pm 0.12 \mathrm{c}$ & $93.43 \pm 0.34 \mathrm{~d}$ & $93.51 \pm 0.26 \mathrm{~d}$ \\
\hline & $55.87 \pm$ & c & $.06 \mathrm{~b}$ & 5 & $55.43 \pm 0.06 \mathrm{~b}$ & $69 \pm 0.0$ & & $54.96 \pm 0.07 \mathrm{c}$ & 54.20 & $15 \mathrm{~d}$ \\
\hline $\mathrm{N}\left(\mathrm{mg} \mathrm{L}^{-1}\right)$ & $85.16 \pm 2.66 \mathrm{e}$ & $157.93 \pm 4.93 \mathrm{a}$ & $87.10 \pm 2.72 \mathrm{e}$ & $126.44 \pm 3.94 b$ & $71.74 \pm 2.24 \mathrm{f}$ & $113.60 \pm 3.61 \mathrm{c}$ & $85.16 \pm 2.66 \mathrm{e}$ & $131.61 \pm 4.11 \mathrm{~b}$ & $46.45 \pm 1.45 \mathrm{~g}$ & $101.21 \pm 3.20 \mathrm{~d}$ \\
\hline $\mathrm{K}\left(\mathrm{mg} \mathrm{L}^{-1}\right)$ & $118.70 \pm 3.70 \mathrm{f}$ & $180.64 \pm 5.64 \mathrm{~d}$ & $232.25 \pm 7.25 c$ & $304.23 \pm 9.51 \mathrm{~b}$ & $381.92 \pm 9.54 \mathrm{a}$ & $372.96 \pm 11.24 \mathrm{a}$ & $103.22 \pm 3.22 \mathrm{f}$ & $154.83 \pm 4.64 \mathrm{e}$ & $103.21 \pm 3.16 \mathrm{f}$ & $147.42 \pm 4.74 \mathrm{e}$ \\
\hline & $36.13 \pm 1.13 \mathrm{e}$ & $66.58 \pm 2.08 b$ & $44.85 \pm 1.40 \mathrm{~d}$ & $71.74 \pm 2.24 \mathrm{ab}$ & $40.77 \pm 1.27 \mathrm{de}$ & $58.35 \pm 1.85 c$ & $44.78 \pm 1.28 \mathrm{~d}$ & $2.16 \mathrm{ab}$ & $37.16 \pm 1.16 \mathrm{e}$ & $74.87 \pm 2.17 \mathrm{a}$ \\
\hline $\mathrm{Ca}(\mathrm{n}$ & $701.91 \pm 21.91 \mathrm{a}$ & $717.54 \pm$ & $701.84 \pm$ & $23=$ & $725.65 \pm$ & 719.42 & $79 \pm 16.29 c$ & $6.38 \mathrm{c}$ & 486.17 & $615.12 \pm 11.87 \mathrm{~b}$ \\
\hline $\mathrm{Mg}\left(\mathrm{mg} \mathrm{L}^{-1}\right)$ & $486.85 \pm 15.21 \mathrm{a}$ & $479.46 \pm 14.96 \mathrm{a}$ & $329.74 \pm 10.29 b$ & $330.93 \pm 9.56 \mathrm{~b}$ & $240.04 \pm 7.49 \mathrm{~d}$ & $236.59 \pm 7.49 \mathrm{~d}$ & $310.56 \pm 9.69 \mathrm{~b}$ & $317.72 \pm 9.92 \mathrm{~b}$ & $241.54 \pm 7.54 \mathrm{~d}$ & $277.54 \pm 8.79 c$ \\
\hline $\mathrm{Na}\left(\mathrm{mg} \mathrm{L}^{-1}\right)$ & $45.93+1.43 c$ & $4645+145$ & $4180+128 c$ & $4593+143 c$ & $42.83+1.33 c$ & $4131+131 c$ & $64.51+2.01 b$ & $18+198 \mathrm{~b}$ & $8928+278 a$ & $85.71 \pm 1.95 \mathrm{a}$ \\
\hline $\mathrm{SO}_{4}-\mathrm{S}\left(\mathrm{mg} \mathrm{L}^{-1}\right)$ & $8.77 \pm 0.27 b$ & $8.26 \pm 0.26 b$ & $6.71 \pm 0.21 c$ & $6.71 \pm 0.21 c$ & $6.70 \pm 0.20 c$ & $6.72 \pm 0.22 c$ & $6.71 \pm 0.21 \mathrm{c}$ & $6.71 \pm 0.20 c$ & $6.19 \pm 0.19 c$ & $13.94 \pm 0.44 \mathrm{a}$ \\
\hline $\mathrm{Fe}\left(\mathrm{mg} \mathrm{L}^{-1}\right)$ & $9.25 \pm 0.29 b c$ & $8.26 \pm 0.21$ cde & $9.54 \pm 0.30 \mathrm{~b}$ & $8.51 \pm 0.23 \mathrm{cde}$ & $8.15 \pm 0.25 \mathrm{de}$ & $7.79 \pm 0.21 \mathrm{e}$ & $8.36 \pm 0.26 \mathrm{cde}$ & $8.64 \pm 0.26 \mathrm{bcde}$ & $9.03 \pm 0.28 \mathrm{bcd}$ & $13.98 \pm 0.45 \mathrm{a}$ \\
\hline $\mathrm{Cu}\left(\mathrm{mg} \mathrm{L}^{-1}\right)$ & $1 \pm 0.00 \mathrm{e}$ & 0 & $4 \pm 0.00 \mathrm{f}$ & $0.04 \pm 0.00 \mathrm{f}$ & $0.04 \pm 0.00 \mathrm{f}$ & 0. & $0.21 \pm 0.01 \mathrm{c}$ & $0.26 \pm 0.01 \mathrm{~b}$ & $0.15 \pm 0.00 \mathrm{~d}$ & $0.31 \pm 0.01 \mathrm{a}$ \\
\hline $\mathrm{Zn}\left(\mathrm{mg} \mathrm{L}^{-1}\right)$ & $1.08 \pm 0.03 \mathrm{~cd}$ & $0.98 \pm 0.03 \mathrm{~d}$ & $1.03 \pm 0.03 \mathrm{~d}$ & $1.18 \pm 0.04 \mathrm{c}$ & $1.03 \pm 0.03 \mathrm{~d}$ & $0.98 \pm 0.03 \mathrm{~d}$ & $1.55 \pm 0.05 b$ & $1.55 \pm 0.05 \mathrm{~b}$ & $2.11 \pm 0.06 \mathrm{a}$ & $2.22 \pm 0.07 \mathrm{a}$ \\
\hline & $2.42 \pm 0.07 \mathrm{~d}$ & $43 \pm 0.07 \mathrm{~d}$ & $8.98 \pm 0.28 b$ & $8.97 \pm 0.027 b$ & $12.95 \pm 0.39 \mathrm{a}$ & $12.75 \pm 0.37 \mathrm{a}$ & $\pm 0.08 \mathrm{~d}$ & $2.68 \pm 0.08 \mathrm{~cd}$ & $.09 \mathrm{~cd}$ & $3.41 \pm 0.11 \mathrm{c}$ \\
\hline $\mathrm{B}\left(\mathrm{mg} \mathrm{L}^{-1}\right)$ & $0.62 \pm 0.02 c$ & $0.62 \pm 0.02 c$ & $0.67 \pm 0.02 c$ & $0.66 \pm 0.02 c$ & $0.67 \pm 0.02 c$ & $0.67 \pm 0.02 c$ & $0.83 \pm 0.03 b$ & $0.83 \pm 0.02 b$ & $0.98 \pm 0.03 a$ & $0.88 \pm 0.03 b$ \\
\hline
\end{tabular}

Values $(n=3)$ in rows followed by the same letter are not significantly different, $p \leq 0.05$. 
In the second experiment (Exp. II), the most promising treatment of biochar was further selected for investigation and examined in four different plant species of high importance and marketability interest for seedling production. Tomato (Solanum lycopersicum cv. Fi Akron), leek (Allium porrum cv. F1 Stamford), geranium (Pelargonium $\times$ hortorum cv. Fi Horizon), and impatiens (Impatiens walleriana $\mathrm{cv}$. F1 New Guinea Divine Orange) seeds were used. Plant growth, nutrients, and physiology-related attributes were examined.

\subsection{Seed Emergence}

Both Exp. I and Exp. II investigated the emergence of seeds. Seeds were sown in plastic seedling trays $\left(1 \mathrm{~cm}\right.$ depth). Each treatment had 18 modules, each with a volume of $40 \mathrm{~cm}^{3}$. Each module was seeded with three seeds. Irrigation took place daily with equal amount of potable water for all growing media. No fertilizers were applied during seedling growth. The recorded maximum and minimum temperatures were $25 \pm 2{ }^{\circ} \mathrm{C}$ and $20 \pm 2{ }^{\circ} \mathrm{C}$, respectively. Day light hours was L:D 16:8 with light flux density $300 \mu \mathrm{mol}$ PAR $\mathrm{m}^{-2} \mathrm{~s}^{-1} \pm 20$.

Seed emergence was observed daily and seeds were marked emerged with the hypocotyl's appearance. Mean emergence time (MET) was calculated as described previously [49].

\subsection{Plant Growth and Nutrient Content}

In six seedlings/treatments, seedlings were recorded with growth-related parameters following 4-6 weeks of plant growth. The seedling height and the number of leaved produced were recorded. The stomatal conductance of leaves was measured with a $\Delta \mathrm{T}$-Porometer AP4 (Delta-T Devices-Cambridge, Burwell, Cambridge, UK) [38]. Leaf chlorophyll fluorescence (chlorophyll fluorometer, opti-sciences OS-30p, UK) was measured on two fully developed, light-exposed leaves per seedling. Following leaves incubation in the dark for $20 \mathrm{~min}$, the Fv/Fm ratio was measured [38]. Leaf chlorophyll content was assayed in six replicates/treatment. Chlorophyll was extracted with dimethyl sulfoxide (DMSO) and Chlorophyll a (Chl a), Chlorophyll b (Chl b) and total Chlorophylls (total Chl) content was determined [38]. Seedlings were sampled above substrate surface, the upper plant part was weighed (g), dried at $85^{\circ} \mathrm{C}$ and then the dry weight (g) was recorded.

Nutrient content was measured in the seedling's upper part (including leaves and shoots) on four replicates/treatment (two pooled plants/replicate). Dried plant tissue (at $65{ }^{\circ} \mathrm{C}$ for $3 \mathrm{~d}$ ) was used $(\sim 0.5 \mathrm{~g})$ and was ashed (at $500{ }^{\circ} \mathrm{C}$ for $\left.5 \mathrm{~h}\right)$ and acid $(2 \mathrm{~N} \mathrm{HCl})$ digested [50]. Nitrogen $(\mathrm{N})$ content was determined with Kjeldahl (BUCHI, Digest automat K-439 and Distillation Kjeldahl K-360) digestion method. Phosphorus content was determined spectrophotometrically (Multiskan GO, Thermo Fisher Scientific, Waltham, MA, USA), and $\mathrm{K}, \mathrm{Mg}, \mathrm{Ca}, \mathrm{Na}, \mathrm{Fe}, \mathrm{Cu}$, and $\mathrm{Zn}$ by an atomic absorption spectrophotometer (PG Instruments AA500FG, Leicestershire, UK) for plant tissue analysis or by inductively coupled plasma atomic emission spectrometry (ICP-AES; PSFO 2.0, Leeman Labs INC., Mason, OH, USA) for growing media analysis [10,38]. Plant nutrient content was expressed in $g$ $\mathrm{kg}^{-1}$ and $\mathrm{mg} \mathrm{kg}^{-1}$ of dry weight, for macronutrients and micronutrients, respectively, and growing media mineral content was expressed in $\mathrm{mg} \mathrm{L}^{-1}$.

\subsection{Total Phenols Content and Antioxidant Capacity}

In the Exp. I, methanolic extracts of four replicates (two pooled plants/replicate) of lettuce grown in different biochar type and ratio were used for total phenols content and total antioxidant activity determination. Total phenols content was determined as previously described [51] and results were expressed as gallic acid equivalents (mg GAE per gram of fresh weight). For antioxidant capacity, two assays were employed, the ferric reducing antioxidant power (FRAP) and the 2,2-diphenyl-1-picrylhydrazyl (DPPH), as described previously [52]. Results were expressed as trolox equivalents ( $\mathrm{mg}$ trolox per gram of fresh weight). 


\subsection{Lipid Peroxidation, Hydrogen Peroxide, and Enzyme Antioxidant Activity}

In the Exp. I, four replicates (two pooled plants/replicate) of each treatment were used for the evaluation of damage index and antioxidant enzymatic activity. Lipid peroxidation (assayed through the malondialdeyde-MDA content) and hydrogen peroxide $\left(\mathrm{H}_{2} \mathrm{O}_{2}\right)$ content were measured $[53,54]$. Results were expressed as $\mu \mathrm{mol} \mathrm{H}_{2} \mathrm{O}_{2}$ per gram of fresh weight, and nmol of MDA per gram of fresh weight.

The enzymes antioxidant activity for superoxide dismutase (SOD), for catalase (CAT) and for peroxidase activity (POD) was assayed as described previously [52]. Results were expressed as enzyme units per mg of protein. The protein content was determined with bovine serum albumin (BSA), as a standard.

\subsection{Statistical Analysis}

A three-factor (Biochar type, Biochar rate and Fertilizer) factorial experiment was carried out. Results were statistically analyzed with a three-way analysis of variance (ANOVA) with the IBM SPSS v.22 software for Windows. The Duncan's Multiple Range test (DMRT) was used for comparing means in case of the effect of factors and their interaction, at $p \leq 0.05$, following one-way ANOVA. Mean values \pm standard error (SE) of three biological replications $(n=3)$ for growing media and of four biological replications $(n=4)$ for plant-related analysis were used.

\section{Results}

Table 2 presents the effects of biochar type, biochar ratio, fertilizer, and their interaction on growing media and plant-related parameters. Biochar type affected significantly growing media parameters (EC, $\mathrm{pH}$, organic matter, organic carbon, $\mathrm{K}, \mathrm{Ca}, \mathrm{Na}, \mathrm{SO}_{4}, \mathrm{Fe}, \mathrm{Cu}, \mathrm{Zn}, \mathrm{Mn}$, and $\mathrm{B}$ at $p<0.001 ; \mathrm{N}$ at $p<0.01$ ) and plant (Fv/Fm, MDA, N, K, P, Ca, Mg, Na, Cu, and Zn at $p<0.001$; height, chlorophylls, FRAP, and SOD at $p<0.05)$. Biochar ratio affected significantly growing media parameters (EC, organic matter, organic carbon, $\mathrm{N}, \mathrm{K}, \mathrm{Mg}, \mathrm{Na}, \mathrm{SO}_{4}, \mathrm{Fe}, \mathrm{Zn}$, and $\mathrm{Mn}$ at $p<0.001 ; \mathrm{P}$ and $\mathrm{B}$ at $\left.p<0.01\right)$ and plant (Fv/Fm, MDA, CAT, POD, N, K, Ca, Mg, Cu, and $\mathrm{Zn}$ at $p<0.001)$. Fertilizer affected significantly growing media parameters (EC, organic matter, organic carbon, $\mathrm{N}, \mathrm{K}, \mathrm{P}, \mathrm{SO}_{4}$, and $\mathrm{Cu}$ at $p<0.001 ; \mathrm{Ca}$, Fe at $p<0.05$ ) and plant-related parameters (height, fresh weight, dry weight, $\mathrm{H}_{2} \mathrm{O}_{2}, \mathrm{POD}, \mathrm{P}, \mathrm{Ca}, \mathrm{Mg}$, Na, and $\mathrm{Cu}$ at $p<0.001$; leaf number, chlorophyll b, MDA, and N at $p<0.01$; chlorophyll a, total chlorophyll, CAT, Fe, and $\mathrm{Zn}$ at $p<0.05)$.

Considering the interaction of the examined factors, Biochar type $\times$ Biochar ratio $(\mathrm{T} \times \mathrm{R})$ affected significantly growing media $\left(\mathrm{pH}\right.$, organic matter, organic carbon, $\mathrm{N}, \mathrm{K}, \mathrm{Na}, \mathrm{SO}_{4}, \mathrm{Fe}, \mathrm{Zn}$, and $\mathrm{Mn}$ at $p<0.001$; B at $p<0.01 ; \mathrm{EC}, \mathrm{P}$ and $\mathrm{Mg}$ at $p<0.05)$ and plant $\left(\mathrm{H}_{2} \mathrm{O}_{2}, \mathrm{MDA}, \mathrm{CAT}, \mathrm{K}, \mathrm{P}, \mathrm{Na}, \mathrm{Cu}\right.$, and $\mathrm{Zn}$ at $p<0.001$; FRAP at $p<0.01$; height, stomatal conductance, chlorophylls, total phenols, DPPH, Mg, and Fe at $p<0.05)$. Biochar type $\times$ Fertilizer $(\mathrm{T} \times \mathrm{F})$ affected significantly growing media $\left(\mathrm{SO}_{4}, \mathrm{Fe}\right.$, and $\mathrm{Cu}$ at $p<0.001$; EC and $\mathrm{P}$ at $p<0.01)$ and plant $\left(\mathrm{H}_{2} \mathrm{O}_{2}, \mathrm{MDA}, \mathrm{N}, \mathrm{K}, \mathrm{P}, \mathrm{Na}\right.$, and $\mathrm{Zn}$ at $p<0.001 ; \mathrm{Fv} / \mathrm{Fm}$ and CAT, at $p<0.01$; stomatal conductance, chlorophylls, and $\mathrm{Cu}$ at $p<0.05)$. Biochar rate $\times$ Fertilizer $(\mathrm{R} \times \mathrm{F})$ affected significantly growing media $\left(\mathrm{SO}_{4}, \mathrm{Fe}\right.$, and $\mathrm{Cu}$ at $p<0.001 ; \mathrm{K}$, at $\left.p<0.01\right)$ and plant (MDA, N, K, P, Na, and Zn, at $p<0.001$; height, stomatal conductance, CAT, Ca, Mg, at $p<0.01$; dry weight, and $\mathrm{Cu}$, at $p<0.05)$. Biochar type $\times$ Biochar rate $\times$ Fertilizer $(\mathrm{T} \times \mathrm{R} \times \mathrm{F})$ affected significantly growing media $\left(\mathrm{P}, \mathrm{SO}_{4}, \mathrm{Fe}\right.$, and $\mathrm{Cu}$ at $p<0.001 ; \mathrm{K}$ at $p<0.01 ; \mathrm{pH}$ and $\mathrm{Ca}$ at $\left.p<0.05\right)$ and plant $(\mathrm{Fv} / \mathrm{Fm}$, $\mathrm{N}, \mathrm{P}$, and Zn at $p<0.001$; height, MDA, and $\mathrm{K}$ at $p<0.01$; leaf number, SOD, and CAT at $p<0.05$ ).

\subsection{Growing Media Properties}

The growing media properties from different mixtures based on different biochars types (BFW or BTS), ratios (7.5\% and $15 \%)$, and fertilizer level (100\% and $150 \%)$ are shown in Table 3 . The addition of NPK-fertilizer at a level of $150 \%$ increased the EC and the levels of N, K, and P at the $100 \%$ fertilized peat $(\mathrm{P}+$ Fert) in comparison to the control $(\mathrm{P})$. Fertilized substrates (+ Fert) of $150 \%$ revealed higher 
EC values compared to the 100\%. The addition of BFW and BTS decreases the EC, more with the former and more at the higher rate of biochar. This was present at both rates of fertilizer (Table 3). BTS-based media had lower organic matter compared with the BFW. Adding BFW at $15 \%$ increased pH value compared to lower ratio (i.e., 7.5\% BFW) or BTS-based media. The adding of BFW and BTS at $15 \%$ into the growing media decreased $\mathrm{N}$ content comparing to the control (peat). This was also evidenced at the $150 \%$ fertilized BFW and BTS even at lower ratio, i.e., at $7.5 \%$, but also at the $15 \%$. Potassium was increased at BFW-based growing media (independently of the fertilization), but decreased at the $150 \%$ fertilized BTS media (i.e., BTS + Fert at 7.5\% and 15\%) in comparison to the relevant control (peat or peat + Fert, respectively). Phosphorus increased at 7.5\% of BFW and BTS compared to peat, increased at BTS + Fert at 15\%, and decreased at BFW + Fert at 15\% compared to the peat + Fert treatment. The addition of BTS into the growing media decreased the Ca, but increased the Na and $B$ levels, independently of the fertilization and/or biochar ratios. Magnesium and sulfur levels were decreased in BFW- and BTS-based media. The addition of BFW decreased Cu while the addition of BTS increased $\mathrm{Cu}$ levels compared to the control. The Zn levels were increased in BTS-based media and in case of BFW + Fert at 7.5\%. Iron content decreased in BFW at 15\%, but increased in BTS + Fert at $15 \%$. Manganese levels were increased in BFW-based media compared with the relevant control (peat or peat + Fert, respectively) (Table 3).

\subsection{Experiment I}

\subsubsection{Seed Emergence}

Biochar BFW at 7.5\% increased seed emergence after 4 days compared to control (peat). Biochar BTS did not change the emergence of lettuce seeds (Figure 1). Neither the type nor the ratio of the examined biochars and applied fertilizers (100\% or 150\%) affected the mean emergence time for lettuce seeds (data not shown).
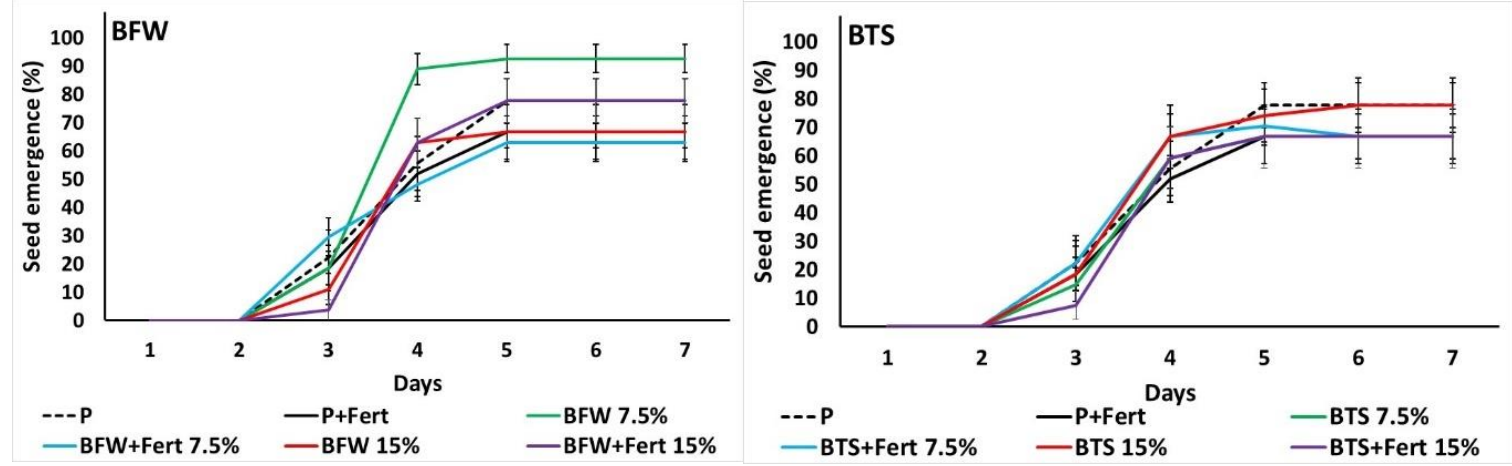

Figure 1. Lettuce cumulative seedling emergence in peat $(\mathrm{P})$ with different biochar types (BFW, BTS) and ratio $(7.5 \%, 15 \%)$ and mineral doses (with standard or with Fertilizers-Fert.). Error bars show SE $(n=4)$.

\subsubsection{Plant Growth and Physiology}

Biochar BFW and BTS either at $7 \%$ or at $15 \%$ reduced plant height, when compared with the control treatment (Table 4). The tallest seedlings were found at the BTS + Fert at 7.5\% treatment. Fertilization at $150 \%$ and biochar type were affecting upper seedling fresh weight as BTS + Fert at 15\% and $\mathrm{BFW}+$ Fert at $7.5 \%$ and at $15 \%$ decreased seedling fresh weight compared with the peat + Fert treatment. BFW + Fert at 15\% and BTS + Fert at 15\% decreased dry weight when compared to control and $7.5 \%$ of $150 \%$ fertilized Biochars (BFW + Fert and BTS + Fert). The number of leaves produced was similar in plants grown on biochar-based media and control (Figure S1), while the higher number of leaves was obtained at the BTS + Fert at 7.5\% and relevant control (Peat + Fert) (Table 4). 
Table 4. Effects of peat (P) with different biochar types (BFW, BTS) and ratio (7.5\%, 15\%) and mineral doses (with standard or with additional Fertilizers-Fert.) on lettuce plant growth (height in $\mathrm{cm}$, upper fresh weight in $\mathrm{g}$, upper dry weight in $\mathrm{g}$, root length in $\mathrm{cm}$ ).

\begin{tabular}{lcccc}
\hline & Height & Leaf Number & Upper Fresh Weight & Upper Dry Weight \\
\hline P & $9.11 \pm 0.71 \mathrm{abc}$ & $5.33 \pm 0.21 \mathrm{ab}$ & $0.908 \pm 0.153 \mathrm{bcd}$ & $0.090 \pm 0.026 \mathrm{bc}$ \\
P + Fert & $9.61 \pm 0.55 \mathrm{ab}$ & $5.50 \pm 0.42 \mathrm{a}$ & $1.588 \pm 0.241 \mathrm{a}$ & $0.207 \pm 0.054 \mathrm{a}$ \\
BFW 7.5\% & $6.50 \pm 0.53 \mathrm{de}$ & $4.16 \pm 0.31 \mathrm{~b}$ & $0.504 \pm 0.053 \mathrm{~d}$ & $0.046 \pm 0.002 \mathrm{c}$ \\
BFW + Fert 7.5\% & $8.30 \pm 0.58 \mathrm{bcd}$ & $5.16 \pm 0.47 \mathrm{ab}$ & $1.061 \pm 0.047 \mathrm{bc}$ & $0.240 \pm 0.051 \mathrm{a}$ \\
BFW 15\% & $6.06 \pm 0.42 \mathrm{e}$ & $4.66 \pm 0.21 \mathrm{ab}$ & $0.603 \pm 0.015 \mathrm{~cd}$ & $0.085 \pm 0.002 \mathrm{bc}$ \\
BFW + Fert 15\% & $8.01 \pm 0.49 \mathrm{bcde}$ & $5.00 \pm 0.25 \mathrm{ab}$ & $0.889 \pm 0.083 \mathrm{~cd}$ & $0.093 \pm 0.018 \mathrm{bc}$ \\
BTS 7.5\% & $6.42 \pm 0.41 \mathrm{de}$ & $4.50 \pm 0.42 \mathrm{ab}$ & $0.570 \pm 0.009 \mathrm{~d}$ & $0.091 \pm 0.000 \mathrm{bc}$ \\
BTS + Fert 7.5\% & $10.83 \pm 1.06 \mathrm{a}$ & $5.50 \pm 0.62 \mathrm{a}$ & $1.341 \pm 0.274 \mathrm{ab}$ & $0.159 \pm 0.011 \mathrm{ab}$ \\
BTS 15\% & $7.01 \pm 0.59 \mathrm{de}$ & $4.83 \pm 0.40 \mathrm{ab}$ & $0.625 \pm 0.063 \mathrm{~cd}$ & $0.089 \pm 0.009 \mathrm{bc}$ \\
BTS + Fert 15\% & $7.56 \pm 0.47 \mathrm{cde}$ & $4.66 \pm 0.33 \mathrm{ab}$ & $0.853 \pm 0.186 \mathrm{~cd}$ & $0.101 \pm 0.018 \mathrm{bc}$ \\
\hline
\end{tabular}

Values $(n=6)$ in columns followed by the same letter are not significantly different, $p<0.05$.

The stomatal conductance of leaves was increased at BFW + Fert at 15\% (Table 5). Leaf chlorophyll fluorescence decreased with the biochars (BFW or BTS) presence at both 7.5 and 15\% ratios. However, fertilization at $150 \%$ increased chlorophyll fluorescence only in the case of BFW at 7.5\%. Chlorophyll a content increased at BTS at 7.5\% and at BTS (at 7.5 and 15\%) + Fert compared to relevant controls (100\% fertilized peat in the first case and $150 \%$ fertilized peat in the latter). Chlorophyll b content was also increased at BTS + Fert, which resulted in increased total chlorophylls content at BTS at 7.5\% and $15 \%$ (Table 5).

Table 5. Effects of peat (P) with different biochar types (BFW, BTS) and ratio (7.5\%, 15\%) and mineral doses (with standard or with additional Fertilizers-Fert.) on lettuce leaf stomatal conductance $\left(\mathrm{cm} \mathrm{s}^{-1}\right)$, chlorophyll fluorescence (Fv/Fm), and chlorophylls (Chl a, Chl b, total Chls) content (mg g ${ }^{-1}$ ).

\begin{tabular}{llllll}
\hline & Stomatal Conductance & Chlorophyll Fluorescence & Chl a & Chl b & Total Chls \\
\hline P & $13.64 \pm 0.60 \mathrm{ab}$ & $0.903 \pm 0.006 \mathrm{~b}$ & $0.621 \pm 0.003 \mathrm{~d}$ & $0.161 \pm 0.001 \mathrm{c}$ & $0.782 \pm 0.001 \mathrm{c}$ \\
P + Fert & $11.41 \pm 1.28 \mathrm{bc}$ & $0.878 \pm 0.007 \mathrm{c}$ & $0.695 \pm 0.035 \mathrm{~cd}$ & $0.184 \pm 0.008 \mathrm{c}$ & $0.879 \pm 0.044 \mathrm{c}$ \\
BFW 7.5\% & $13.70 \pm 2.12 \mathrm{ab}$ & $0.871 \pm 0.005 \mathrm{c}$ & $0.638 \pm 0.093 \mathrm{~cd}$ & $0.165 \pm 0.027 \mathrm{c}$ & $0.804 \pm 0.121 \mathrm{c}$ \\
BFW + Fert 7.5\% & $8.41 \pm 0.68 \mathrm{c}$ & $0.919 \pm 0.002 \mathrm{a}$ & $0.681 \pm 0.055 \mathrm{~cd}$ & $0.177 \pm 0.018 \mathrm{c}$ & $0.858 \pm 0.074 \mathrm{c}$ \\
BFW 15\% & $11.01 \pm 0.91 \mathrm{bc}$ & $0.865 \pm 0.003 \mathrm{c}$ & $0.795 \pm 0.032 \mathrm{bcd}$ & $0.202 \pm 0.007 \mathrm{bc}$ & $0.997 \pm 0.040 \mathrm{bc}$ \\
BFW + Fert 15\% & $17.26 \pm 1.03 \mathrm{a}$ & $0.868 \pm 0.001 \mathrm{c}$ & $0.822 \pm 0.086 \mathrm{bcd}$ & $0.214 \pm 0.022 \mathrm{bc}$ & $1.037 \pm 0.109 \mathrm{bc}$ \\
BTS 7.5\% & $16.13 \pm 2.29 \mathrm{a}$ & $0.865 \pm 0.003 \mathrm{c}$ & $0.830 \pm 0.045 \mathrm{bc}$ & $0.207 \pm 0.009 \mathrm{bc}$ & $1.036 \pm 0.054 \mathrm{bc}$ \\
BTS + Fert 7.5\% & $7.13 \pm 1.70 \mathrm{c}$ & $0.838 \pm 0.001 \mathrm{~d}$ & $1.139 \pm 0.108 \mathrm{a}$ & $0.308 \pm 0.030 \mathrm{a}$ & $1.446 \pm 0.138 \mathrm{a}$ \\
BTS 15\% & $9.33 \pm 1.67 \mathrm{bc}$ & $0.825 \pm 0.007 \mathrm{~d}$ & $0.661 \pm 0.037 \mathrm{~cd}$ & $0.168 \pm 0.008 \mathrm{c}$ & $0.830 \pm 0.045 \mathrm{c}$ \\
BTS + Fert 15\% & $7.33 \pm 1.19 \mathrm{c}$ & $0.838 \pm 0.002 \mathrm{~d}$ & $0.939 \pm 0.048 \mathrm{~b}$ & $0.246 \pm 0.013 \mathrm{~b}$ & $1.185 \pm 0.061 \mathrm{~b}$ \\
\hline
\end{tabular}

Values $(n=6)$ in columns followed by the same letter are not significantly different, $p<0.05$.

\subsubsection{Total Phenol Content and Antioxidant Activity}

Total phenol content decreased at 7.5\% BFW and 15\% BTS, independently of the fertilization scheme (Figure 2A). BFW presence at 7.5\%, independently of the fertilization, decreased the antioxidant activity (as assayed by DPPH and FRAP) of lettuce, while in the case of BTS, DPPH and FRAP were decreased at $100 \%$ fertilized BTS at $7.5 \%$ and $15 \%$ (Figure $2 \mathrm{~B}, \mathrm{C}$ ). 

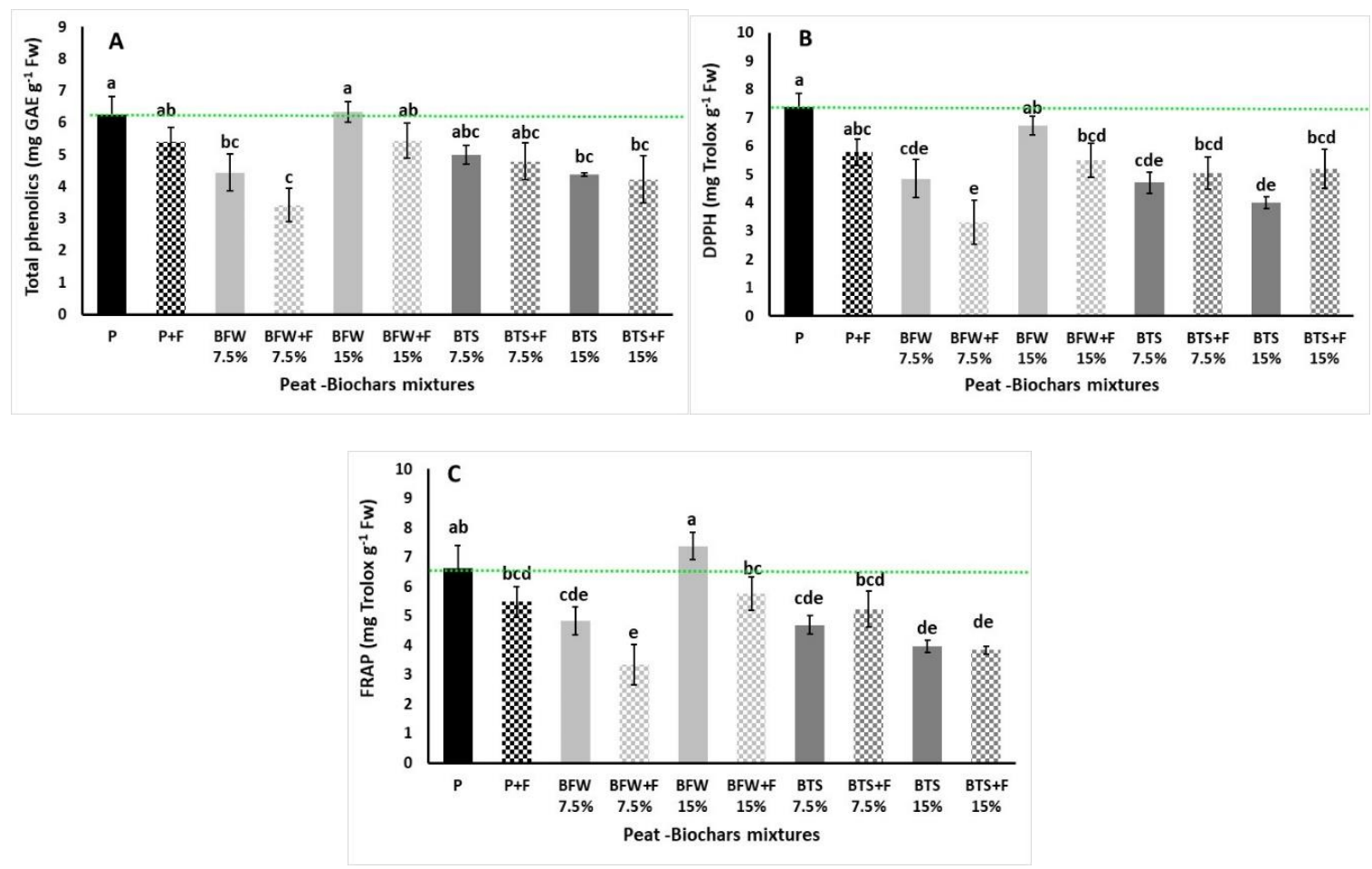

Figure 2. Effects of peat $(\mathrm{P})$ with different biochar types (BFW, BTS) and ratio $(7.5 \%, 15 \%)$ and mineral doses (with standard or with additional Fertilizers-F.) on lettuce total phenols and antioxidant activity. (A) total phenols, (B) DPPH, and (C) FRAP. Significant differences $(p<0.05)$ among treatments are indicated by different letters. Error bars show SE $(n=4)$. Dotted line presents the levels of control treatment (100\% peat).

\subsubsection{Lipid Peroxidation, Hydrogen Peroxide, and Enzyme Antioxidant Activity}

The $150 \%$ fertilized peat (peat + Fert) revealed increases in the plant lipid peroxidation (MDA) when compared to the standard rate of fertilized (control) treatment (Figure 3A). Moreover, MDA increased at $7.5 \%$ and $15 \% \mathrm{BFW}$ and at BFW + Fert at $15 \%$ in comparison to peat. In the case of BTS, MDA content increased at $7.5 \%$ and $15 \%$ BTS as well as the BTS + Fert at 7.5\%, but MDA decreased at BTS + Fert at $15 \%$ compared to relevant controls. The MDA increases were followed by the increased trend of production of hydrogen peroxide in most cases (Figure 3B). Antioxidant enzymes have fluctuated among the treatments, so that the plants can detoxify the elevated stress. SOD activity increased for BTS + Fert at 7.5\% and BTS at 15\%, when compared to the relevant control (Figure 3C). CAT antioxidant enzymatic activity was decreased for BFW at 15\% (independently of the fertilization) treatments and for BTS at 15\% (Figure 3D). POD activity at the 150\% fertilized peat (P + Fert) increased compared to the $100 \%$ peat (Figure $3 \mathrm{E}$ ). POD activity decreased for the BFW at $15 \%$, BTS at $7.5 \%$, BTS at $15 \%$ compared to peat. Fertilized (at 150\%) Biochars (BFW and BTS) decreased POD activity compared with the relevant control (peat + Fert). 

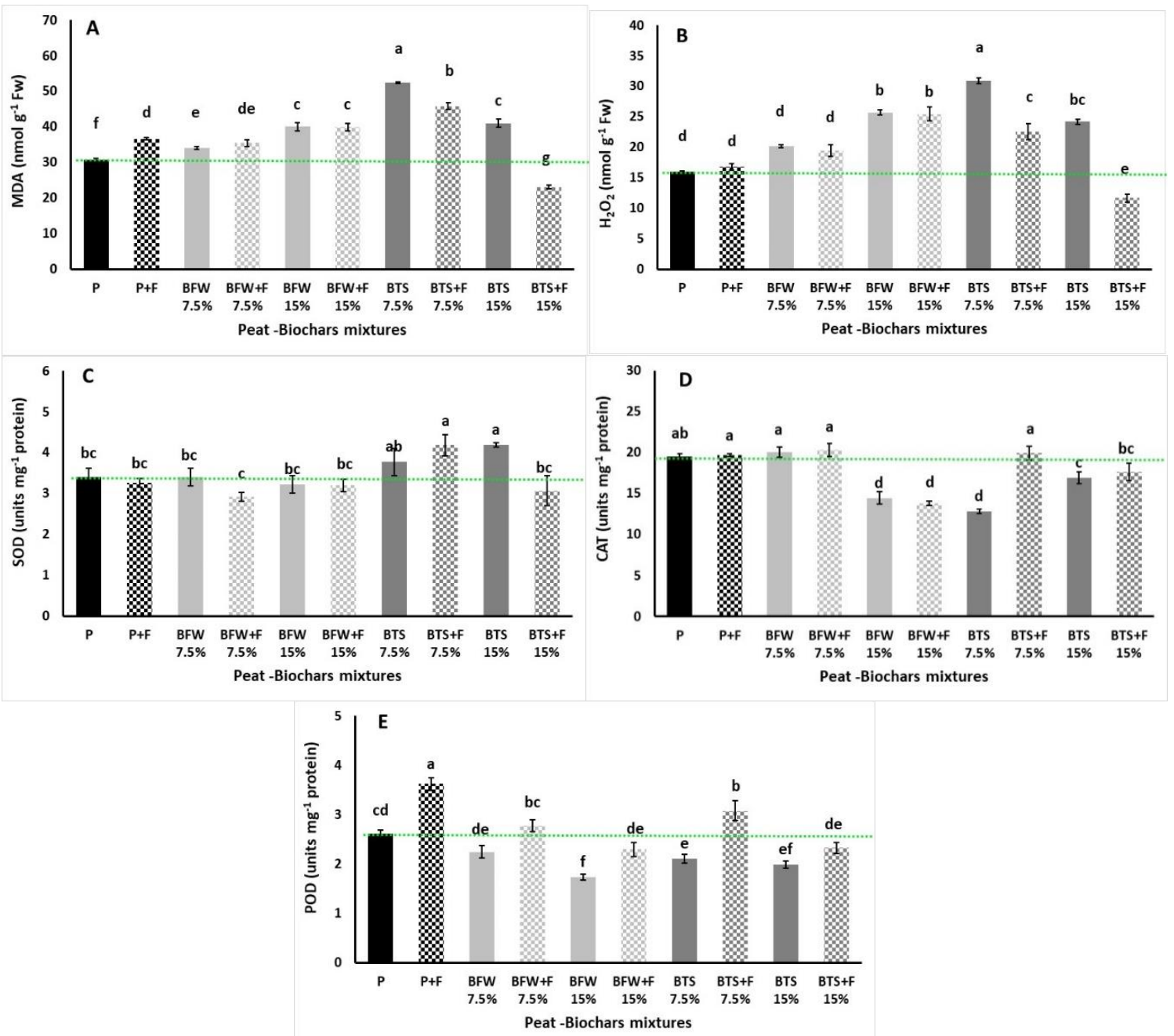

Figure 3. Effects of peat (P) with different biochar types (BFW, BTS) and ratio (7.5\%, 15\%) and mineral doses (with standard or with additional Fertilizers-F) on lettuce lipid peroxidation, hydrogen peroxide and antioxidant enzymes activity. (A) Lipid peroxidation (MDA), (B) $\mathrm{H}_{2} \mathrm{O}_{2},($ C) superoxide dismutase (SOD), (D) catalase (CAT), and (E) peroxidase activity (POD). Significant differences $(p<0.05)$ among treatments are indicated by different letters. Error bars show SE $(n=4)$. Dotted line presents the levels of control treatment ( $100 \%$ peat).

\subsubsection{Nutrient Content}

The addition of $150 \%$ fertilizers in peat, increased the $\mathrm{N}, \mathrm{P}, \mathrm{Mg}$, and $\mathrm{Na}$ but decreased $\mathrm{Ca}$ and $\mathrm{Cu}$ accumulation in lettuce seedlings (Figure 4A-I). The BTS at 7.5\% increased further the $\mathrm{N}$ accumulation in lettuce, while BFW at $15 \%$, BTS at $15 \%$, and $150 \%$ fertilized BFW and BTS at both rations decreased the $\mathrm{N}$ content in lettuce in comparison to the plants grown in control (Figure 4A). BFW significantly increased the accumulation of $\mathrm{K}$ in seedlings, as both the Biochar ratios and the fertilizer presence, increased the K content in plants. Nonetheless, BTS decreased in general the K content in lettuce and was necessary to be fertilized at $150 \%$ and used at $15 \%$ into the growing media so to increase the $\mathrm{K}$ content in lettuce seedling to levels comparable to the control (peat) (Figure 4B). The P content decreased at $15 \%$ BFW and BTS at $7.5 \%$ and $15 \%$ compared to peat, while BFW + Fert and BTS + Fert resulted in decreased $\mathrm{P}$ content in lettuce, independently of the ratio of $7.5 \%$ or $15 \%$ used (Figure $4 \mathrm{C}$ ). A similar trend to $\mathrm{P}$ was observed in the plant tissue for the $\mathrm{Mg}$ accumulation (Figure $4 \mathrm{E}$ ). Calcium content in lettuce was accumulated less with BFW at $7.5 \%$ and at $15 \%$ and BTS at $7.5 \%$ compared to peat, but Ca content was increased with BTS + Fert at 15\% (Figure 4D). Sodium was accumulated more in plants grown at BTS at 15\% (no matter the dosage of fertilizer) and lesser at BFW at 15\% (independent 
of the fertilizers levels) and BFW + Fert at 7.5\% compared to the relevant controls (Figure 4F). Biochar presence at $7.5 \%$ for BTS and at $15 \%$ for BFW and BTS decreased the Fe content in lettuce, while the $150 \%$ fertilization alleviated this effect, as Fe content was in comparable levels to peat-based growing media (without Biochar) (Figure 4G). Copper levels were increased with the adding of BTS and/or fertilizers, but decreased with the BFW at 7.5\% (Figure $4 \mathrm{H}$ ). A similar tendency to $\mathrm{Cu}$ was observed for $\mathrm{Zn}$ accumulation with exception the decreased Zn content with the BTS at $7.5 \%$ compared to the control treatment (Figure 4I).

\subsection{Experiment II}

\subsubsection{Seed Emergence}

In tomato, no differences were found on seed emergence percentage and MET (Figure S2). The first seed emergence took place on day 4 , while all seeds were emerged on the 5 th day. In leek, seed emergence percentage increased (up to 60\%) in Biochar-based media when compared to the control (100\% peat) and significant differences were found after the 11th day (Figure S2). There were not any delays on the emergence time as the MET was similar for control and Biochar-based media. In geranium, a slight increase on seed emergence was found in Biochar-based media however, the effects ended up not to be significant at the end (Figure S2). No differences were found on MET among the examined growing media. In impatiens, the first seed emergence took place on the 9th day and the emergence was completed on the day 16 (Figure S2). Seed emergence on the Biochar-based media was significantly increased up to the 12th day compared with the relevant emergence on the control treatment. MET was decreased in biochar-based growing media. In tomato, seed emergence decreased in biochar-based media after the 4th day, while MET was the same for peat and biochar-based media (Figure S2).

\subsubsection{Effects on Plant Growth, Physiology, and Nutrient Content}

In tomato, BFW + Fert at 7.5\% increased plant height and K accumulation, but decreased leaf stomatal conductance and P levels compared to plants grown in peat (control) (Figure 5). In leak, Biochar presence increased seedling dry weight, and the levels of chlorophylls (Chlorophyll a, Chlorophyll $\mathrm{b}$ and total Chlorophylls), but decreased the nutrient accumulation by decreasing $\mathrm{N}, \mathrm{K}$, and P levels. In geranium, plants grown in Biochar-enriched growing media revealed higher plant height, dry weight, and $\mathrm{K}$ content compared to the control treatment. In impatiens, Biochar presence increased leaf number, $\mathrm{P}$, and $\mathrm{K}$ content, but decreased chlorophyll fluorescence, Chlorophylls content, and $\mathrm{N}$ content compared to the peat (control) (Figure 5). 

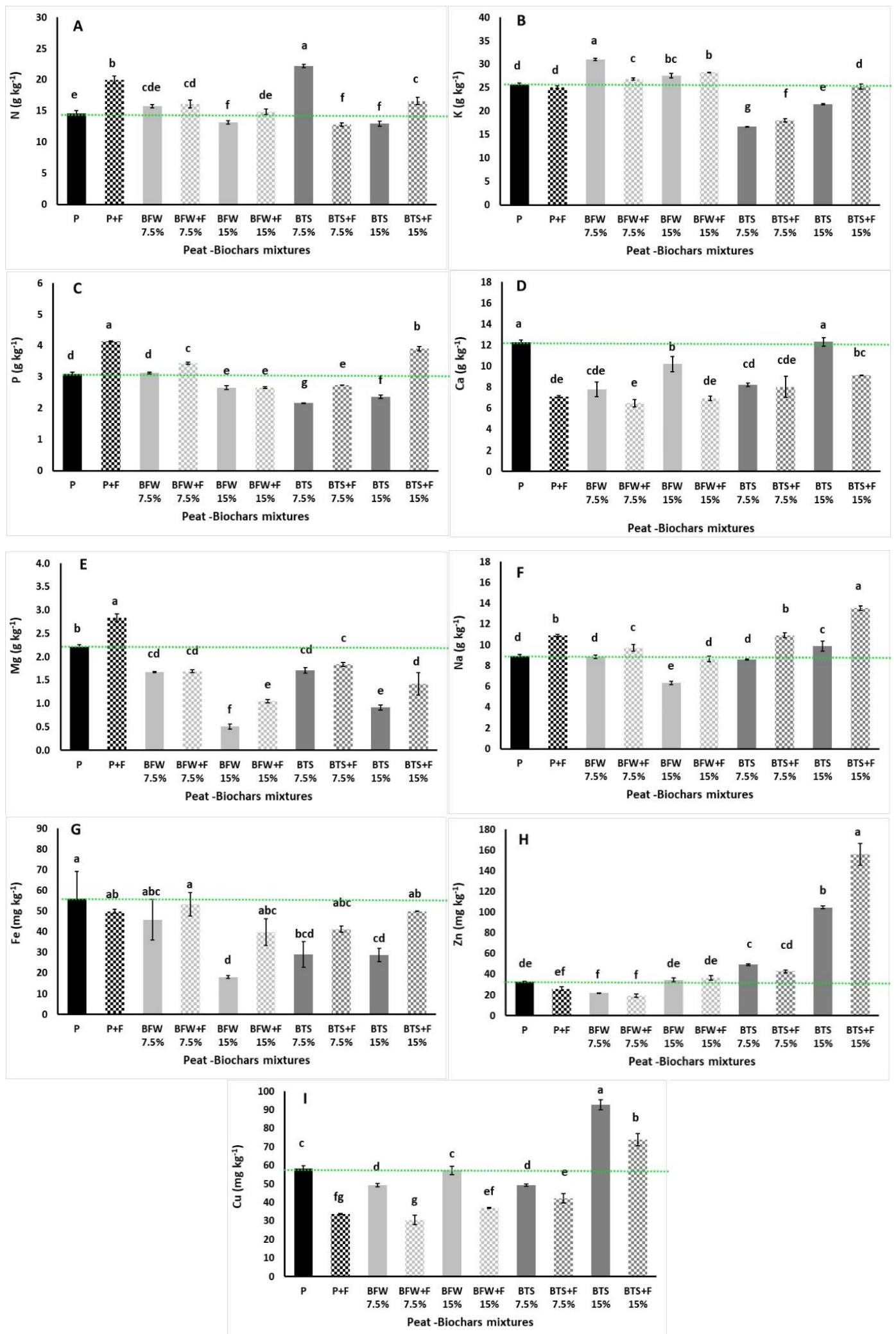

Figure 4. Effects of peat $(\mathrm{P})$ with different biochar types (BFW, BTS) and ratio $(7.5 \%, 15 \%)$ and mineral doses (with standard or with additional Fertilizers-F) on lettuce macro- and micronutrient content. Significant differences $(p<0.05)$ among treatments are indicated by different letters. Error bars show SE $(n=4)$. Dotted line presents the levels of control treatment $(100 \%$ peat). 

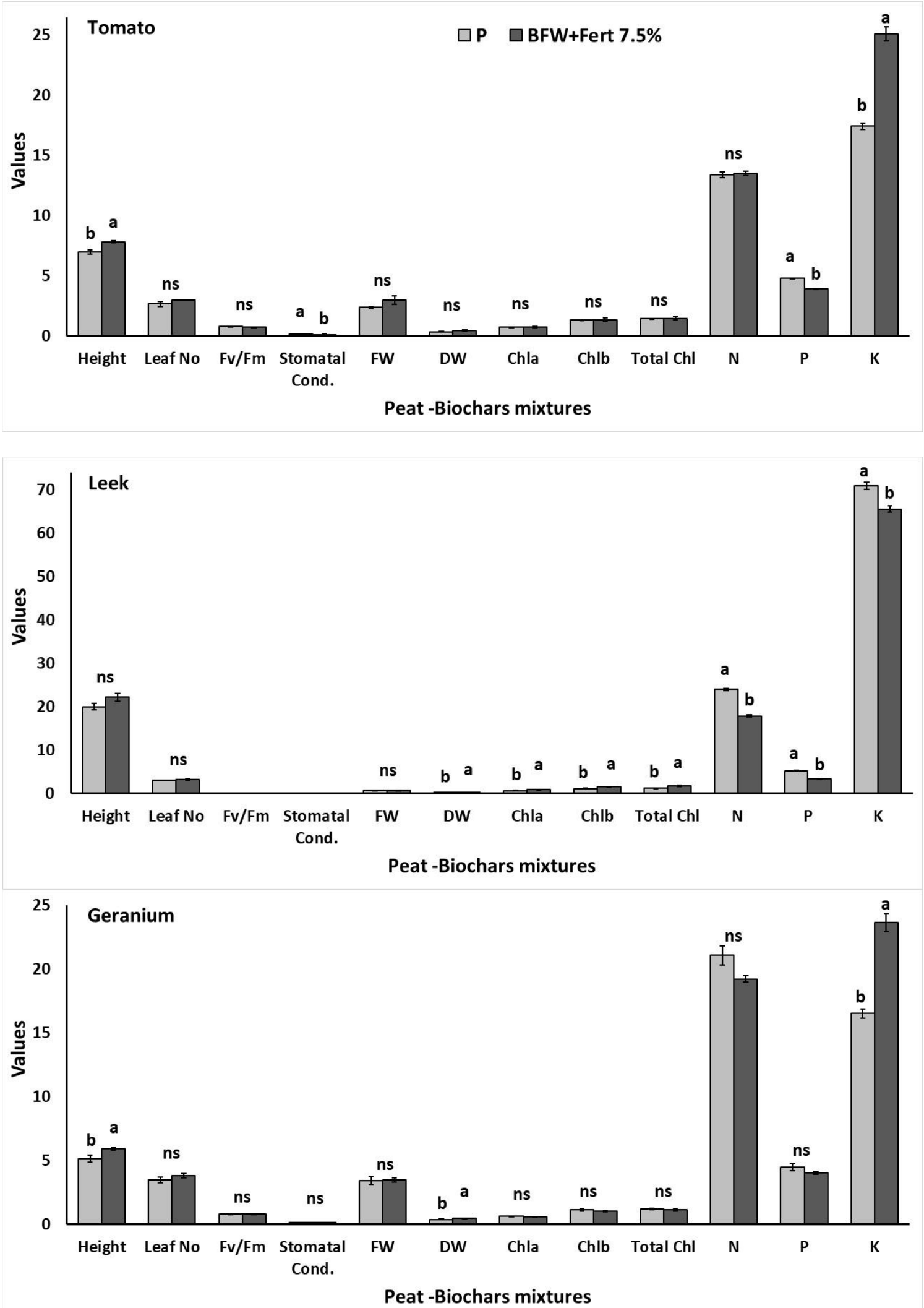

Figure 5. Cont. 


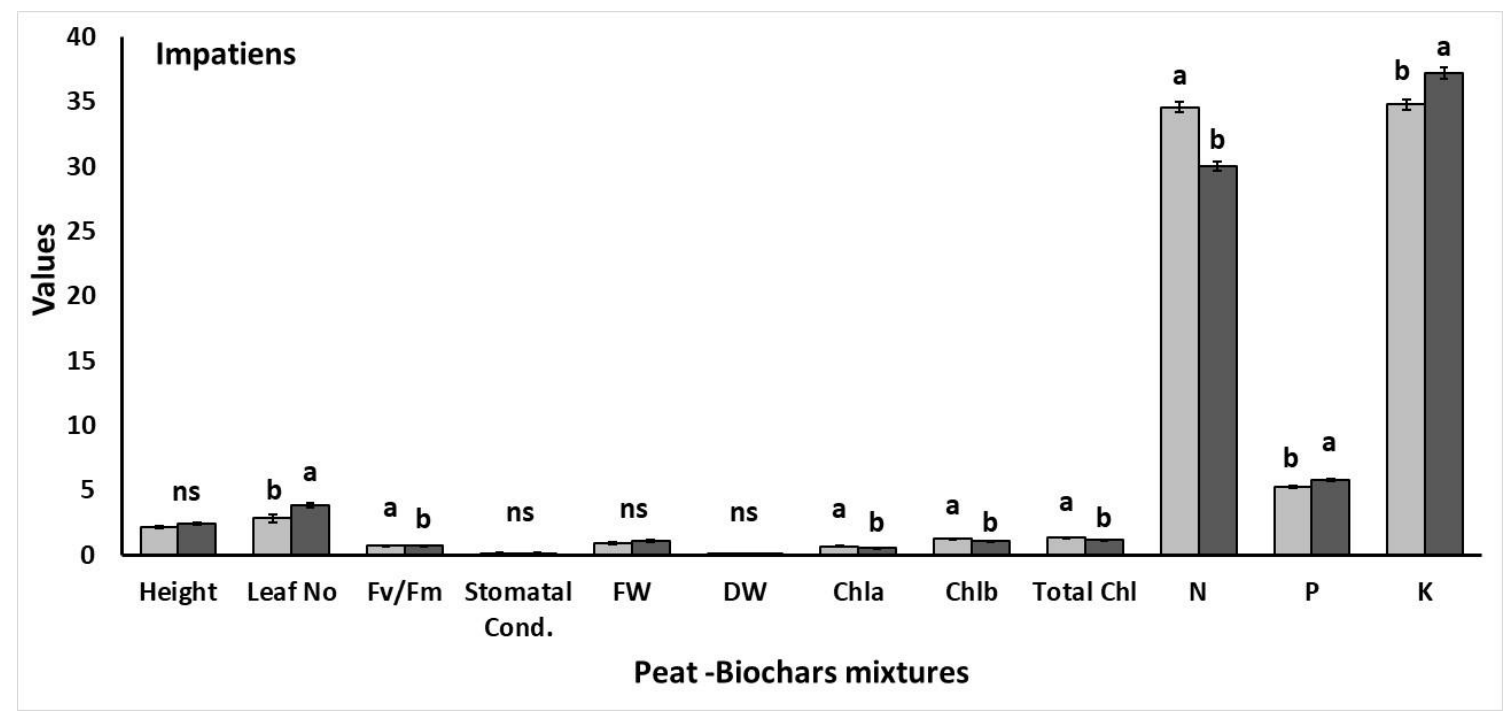

Figure 5. Effects of peat (P; light grey) with BFW at 7.5\% (dark grey) with additional Fertilizers-Fert. on tomato, leek, geranium, and impatiens plant growth, physiology, and nutrient content-related parameters. Significant differences $(p<0.05)$ among treatments are indicated by different letters. Error bars show SE $(n=4)$. ns: not significant.

\section{Discussion}

In the present study, biochar type and ratio as well as fertilization levels were examined for lettuce seedling production and affected lettuce growth and physiology-related attributes with the levels of fertilization impacting plant performance. However, optimized biochar and fertilizer application do not have the same impacts on different plant species and selection should be on a plant-species based strategy. Biochar production is of different organic materials including urban wastes (garden pruning waste), agricultural waste (straw, residue from greenhouse crops, olive-mill waste, by-products from vineyards), food waste, digestate, and even sewage sludge [55-57], and different sources of organic material result in different biochar quality, as presented in Table 1.

In the present study, the increased $\mathrm{pH}$ is in line with numerous studies on Biochar-based material derived from forest waste [5], tomato crop green and wood waste [10,58], wheat straw [14], and hardwood waste [59]. The increase of $\mathrm{pH}$ following biochar addition is beneficial for acidic soil or growing media (as is the case for peat in the present work), with biochar serving as a liming agent and likely replacing the calcium oxide used to increase the $\mathrm{pH}[60,61]$. However, there is need for caution, as we have shown that biochars of similar $\mathrm{pH}$ can have different levels of extractable Ca [62]. The low ratio of biochars employed in the present study retained $\mathrm{pH}$ values between 5.0 and 7.0, since the ideal substrate $\mathrm{pH}$ for peat substrate is between 5.0 and 5.5 [63]. Moreover, biochar-based media had lower EC than standard fertilized peat (control) and was related to rate of application with the higher rate $(15 \%)$ to be more effective than $5 \%$ and the biochar with higher surface area being more effective, in accordance with previous reports [10]. This finding has very serious implications, as materials widely used for peat dilution have usually high levels of EC, such as compost from green waste [64]. Those materials could be used in combination with biochar at a higher ratio since high EC is commonly a limiting factor to be added to these materials. Wang et al. [65] also found that Biochar derived from woody feedstock with higher lignin content and greater surface area revealed different metal sorption capabilities. However, additional studies on biochar type and rate applied on other crops, and at different growth stage apart from seedlings, are required before final conclusions are made. We had previously discussed the possible reason for decreased/low levels of nitrate and of P [10], while Altland and Locke [66] documented P release of biochar from rice husks, with further studies required to understand the mechanism involved. There are various reasons for the retention of nitrate and phosphate in biochar amended growing media. Biochar provides refugee for soil 
microorganism to influence the binding of carbon and anions [67]. Another explanation could be that due to improvement of the root milieu due to addition of biochar e.g., due to soluble organic carbon and this leads in increased microbial activity. Accelerated metabolism of soil biota turns the inorganic nitrogen into organic form, hence less available $\mathrm{N}$ and less $\mathrm{N}$ uptake [68]. The reduction of phosphate availability and uptake could be due to increased availability of $\mathrm{Ca}$ and $\mathrm{Mg}$, due to addition of biochar [69]. Finally, increased surface area and net surface charge may also be responsible [70]. Kammann et al. [71] hypothesized that surface ageing plus non-conventional ion-water bonding in micro- and nano-pores enhanced the capture of nitrates in the biochar particles. Amending (N-rich) bio-waste with biochar may promote its agronomic value and reduce nutrient losses from bio-wastes and agricultural soils.

Biochar BFW at 7.5\% stimulated seed emergence compared to the control, but this was not evidenced at the BTS. One possible explanation for that is that BFW had increased K levels compared with BTS, and priming effect of extra $\mathrm{K}$ on seed germination is already documented in Chinese cabbage [72]. Under nursery conditions, the consistent and fast emergence of seeds is required to meet the increased demands of healthy plant material, delivered to the producers.

Lettuce seedling height was decreased with the presence of BFW or BTS, independently of the biochar ratio, which can be of benefit for a nursery, as shorter plants can be handled, transported, and stored easier than taller plants. BFW and BTS were nutrient rich (EC ranged from $0.41-0.61 \mathrm{mS} \mathrm{cm}^{-1}$ ) materials, but in the present study, they were used in low levels $(7.5-15 \% v / v)$ from one hand, while the fertilized peat used, was a more nutrient rich (higher EC) component compared to biochar-based growing media. Therefore, the reduced plant height might be attributed to the decreased available nutrients to the roots and/or due to the different particle size/surface area and extractable nutrients, i.e., $\mathrm{Ca}$ at the biochar-based media [62]. Therefore, the decreased plant height cannot be considered of disadvantage at all. Based on that, plant fresh weight was not affected by the biochar type and ratio used. However, when fertilization took place, plant fresh biomass decreased in both BFW and BTS, dry weight decreased at $15 \%$ fertilized biochar's media, indicating an increased stress condition due to the overloaded fertilizers particularly $\mathrm{K}$, without affecting the number of leaves produced per plant. High ratio of biochar (up to $20 \%$ ) and different biochar type can affect the cabbage seedling production, as biochar from bamboo or from husks and paper fiber wood screenings affected negatively plant growth and successful cabbage seedling production [34].

Growing media with low biochar rates, for example 10\% sewage-sludge derived biochar in lettuce [73] and 10\% wood-derived biochar in pepper (Capsicum annuum L.) and tomato [74], promoted plant growth. Similar to our findings based on the low biochar ratio used (i.e., 7.5\%), Kim et al. [75] reported increased dry weight of kale (Brassica olereaseae L.) shoots with the use of low biochar levels (i.e., $5 \%$ rice husk biochar) into a coir dust-based media. However, other studies reported no effects of biochar on plant dry weight in tomato and marigold (Tagetes erecta L.) [22] and sunflower (Helianthus annuus L.) [21]. This fluctuation of results among studies might be related to the different biochar sources (wood, straw) and method of production, thus quality, the ratio used (from $5 \%$ up to $75 \%$ ), and the plant species [5]. Mendez et al. [3] mixed biochar with peat to grow lettuce revealed higher quality plants in comparison to those cultivated in single substrate. Changes in chlorophyll fluorescence is affecting the efficiency of PSII photochemistry and the plant photosynthetic performance [38], and this was evidenced at biochar-based media that revealed decreased leaf chlorophyll fluorescence and plant height. Leaf stomatal conductance increased at BFW+Fert at 15\%. Andrographis paniculate (kalmegh) herb grown in biochar-based media mitigated drought stress altering plant metabolism, decreasing the stomatal conductance and increased the water use efficiency under such conditions [7].

Total phenols content did not differ much among the examined treatments, except for the decreased total phenols content in BFW at 7.5\% and BTS at 15\%. Lettuce antioxidant activity (DPPH, FRAP) decreased in most cases of BWF and BTS presence indicating the reduced capacity of the plant to withstand oxidative stress and which is less appreciated and accepted by consumers and markets/industry, who are seeking added value products of high antioxidant status [76]. In contrast, 
total phenols content and antioxidant activity were increased in the case of high biochar ratio and/or fertilizer for cabbage, as reported by Chrysargyris et al. [34]. Even though total phenols and antioxidants remained low, lettuce plants were subjected to oxidative stress with the presence of biochars (BFW, BTS) and/or fertilizers as revealed by the increased levels of MDA, indicating lipid peroxidation and cellular damage. This was further supported with the increased levels of $\mathrm{H}_{2} \mathrm{O}_{2}$ and the activation of SOD and POD antioxidant enzymes to detoxify the reactive oxygen species (ROS) accumulation [52]. Plants responded to oxidative stress by activation of protecting mechanism, producing stress response proteins and antioxidant enzymes (including SOD, POD, and CAT) to resolve the accumulation of ROS [77].

Increased $\mathrm{K}$ levels are not directly toxic to plants however, the increased $\mathrm{K}$ levels can cause antagonism and resulted in $\mathrm{Mg}$ and Ca deficiencies with decreases in plant growth [78]. In the present study, decreased Mg levels in lettuce were evidenced in biochar-based media, those media that had lower Mg and higher K content compared to control media (peat). Similarly, lower $\mathrm{Mg}$ was recorded when Biochars was added to a peat growing media [10]. Moreover, K accumulated in lettuce produced in BFW-based media with more pronounced effects at high ratio and/or fertilizer, whereas BTS had to be fertilized at 150\% and mixed at $15 \%$ to obtain K levels such as control. Similarly, when Syngonium podophyllum was grown in various Biochar-based media, increased K content was found and this was related to the higher level of this element in the growing media [14]. Fertilized $(150 \%)$ biochar-based media and BFW and BTS at high ratio, decreased N and P content in lettuce, being in accordance with findings of our previous studies [10]. In contrast, Kim et al. [75] documented increase contents of $\mathrm{N}$ and $\mathrm{P}$ in kale shoots when Biochar was added at different ratios with the growing media. Calcium content was decreased in lettuce grown in BFW (at 7.5-15\%) and BTS (at 7.5\%) -based media and fertilization at $150 \%$ were needed to overcome this decrease. Biochar presence in general decreased the Fe content in lettuce but fertilization alleviated this effect, as the content of Fe was similar to that of peat-based substrates (without Biochar). Copper and $\mathrm{Zn}$ content in lettuce were increased by adding BTS and/or fertilizers in the growing media with more profound effect at the higher ratio of $15 \%$, and this is reflecting the increased $\mathrm{Cu}$ and $\mathrm{Zn}$ levels into the growing media.

Following selection of BFW at $7.5 \%$ with $150 \%$ fertilization, seed emergence was improved in leek and impatiens, but not in tomato and geranium. In tomato, geranium, and impatiens BFW + Fert at $7.5 \%$ increased several plant-growth related parameters and nutrient accumulation, mainly of $\mathrm{K}$ compared to the control. However, in some cases, such as tomato, leaf stomatal conductance decreased in plants grown in biochar-based media.

\section{Conclusions}

In conclusion, Biochar increased plant growth (biomass, height) at a low ratio (7.5\%), while it reduced the emergence of lettuce seed and plant height at $15 \%$. The addition of Biochars provided nutrients in the seedlings, because the plants could absorb more available nutrients. Production of low-weight seedlings may be beneficial to nurseries when they want to produce dwarf plants and overhead irrigation. This helps to conditions for transport and storage. It seems better to use a wooden biochar of beech, spruce, and pine species produced at $700{ }^{\circ} \mathrm{C}$ with the Schotteredorf process and to use the resulting Biochar (BFW) at a ratio of $7.5 \%$ for the production of lettuce seedlings. Different species however need to be assessed accordingly. These results showed clearly the ability of biochars to reduce EC depending on rate of application and biochar surface area. This finding is very significant as most materials used to dilute peat e.g., composted greenwaste have high EC and the limiting factor on the rate of peat dilution are their high EC. These results also clearly showed that any investigation into the suitability of adding biochar to peat as peat replacement and/or biostimulant, must consider the nutrient implications of this addition to the plant. In addition, bringing the nutrient to the levels based on calculation e.g., peat growing media, may not be enough as there is a strong interaction between biochar and $\mathrm{N}$ and $\mathrm{P}$ availability as based on our substrate analysis and plant nutrient uptake 
data. This area of work needs attention when experiments are conducted to evaluate biochar as an addition to peat and to other growing media.

Supplementary Materials: The following are available online at http:/www.mdpi.com/2073-4395/10/9/1421/s1, Table S1: Growing media composition. Figure S1: Lettuce seedling production in peat with different biochar types (BFW, BTS) and ratio $(7.5 \%, 15 \%)$ and nutrient doses. Figure S2. Effects biochar BFW at 7.5\% with additional Fertilizers-Fert. on tomato, leek, geranium, and impatiens seed emergence and mean emergence time.

Author Contributions: Conceptualization, M.P. and N.T.; methodology, M.P. and N.T.; software, N.T.; validation, A.C., M.P., and N.T.; formal analysis, A.C. and M.P.; investigation, A.C. and A.K.; resources, A.K. and N.T.; data curation, A.C. and M.P.; writing - original draft preparation, A.C.; writing-review and editing, M.P. and N.T.; visualization, A.K.; supervision, M.P. and N.T.; project administration, M.P. and N.T.; funding acquisition, A.K. and N.T. All authors have read and agreed to the published version of the manuscript.

Funding: This research was funded by Bord na Mona Horticulture Ltd. and Cyprus University of Technology under the project OPTIBIOCHAR.

Acknowledgments: The authors are grateful to the project OPTIBIOCHAR that has been developed under the Cooperation Programme Cyprus-Ireland, co-funded by the Bord na Mona LtD and Cyprus University of Technology. Moreover, we are grateful to the reviewer for their substantial and critical contribution during the review/evaluation process.

Conflicts of Interest: The authors declare no conflict of interest.

\section{References}

1. Solaiman, Z.M.; Murphy, D.V.; Abbott, L.K. Biochars influence seed germination and early growth of seedlings. Plant Soil 2012, 353, 273-287. [CrossRef]

2. Laghari, M.; Hu, Z.; Mirjat, M.S.; Xiao, B.; Tagar, A.A.; Hu, M. Fast pyrolysis biochar from sawdust improves the quality of desert soils and enhances plant growth. J. Sci. Food Agric. 2016, 96, 199-206. [CrossRef]

3. Méndez, A.; Paz-Ferreiro, J.; Gil, E.; Gascó, G. The effect of paper sludge and biochar addition on brown peat and coir based growing media properties. Sci. Hortic. Amst. 2015, 193, 225-230. [CrossRef]

4. Agegnehu, G.; Bass, A.M.A.M.; Nelson, P.N.P.N.; Bird, M.I.M.I. Benefits of biochar, compost and biochar-compost for soil quality, maize yield and greenhouse gas emissions in a tropical agricultural soil. Sci. Total Environ. 2016, 543, 295-306. [CrossRef]

5. Belda, R.M.; Lidón, A.; Fornes, F. Biochars and hydrochars as substrate constituents for soilless growth of myrtle and mastic. Ind. Crop. Prod. 2016, 94, 132-142. [CrossRef]

6. Calamai, A.; Palchetti, E.; Masoni, A.; Marini, L.; Chiaramonti, D.; Dibari, C.; Brilli, L. The influence of biochar and solid digestate on rose-scented geranium (Pelargonium graveolens L'Hér.) productivity and essential oil quality. Agronomy 2019, 9, 260. [CrossRef]

7. Saha, A.; Basak, B.B.; Gajbhiye, N.A.; Kalariya, K.A.; Manivel, P. Sustainable fertilization through co-application of biochar and chemical fertilizers improves yield, quality of Andrographis paniculata and soil health. Ind. Crop. Prod. 2019, 140, 111607. [CrossRef]

8. Huang, L.; Niu, G.; Feagley, S.E.; Gu, M. Evaluation of a hardwood biochar and two composts mixes as replacements for a peat-based commercial substrate. Ind. Crop. Prod. 2019, 129, 549-560. [CrossRef]

9. Lashari, M.S.; Ye, Y.; Ji, H.; Li, L.; Kibue, G.W.; Lu, H.; Zheng, J.; Pan, G. Biochar-manure compost in conjunction with pyroligneous solution alleviated salt stress and improved leaf bioactivity of maize in a saline soil from central China: A 2-year field experiment. J. Sci. Food Agric. 2015, 95, 1321-1327. [CrossRef]

10. Prasad, M.; Tzortzakis, N.; McDaniel, N. Chemical characterization of biochar and assessment of the nutrient dynamics by means of preliminary plant growth tests. J. Environ. Manag. 2018, 216, 89-95. [CrossRef]

11. Nadeem, S.M.; Imran, M.; Naveed, M.; Khan, M.Y.; Ahmad, M.; Zahir, Z.A.; Crowley, D.E. Synergistic use of biochar, compost and plant growth-promoting rhizobacteria for enhancing cucumber growth under water deficit conditions. J. Sci. Food Agric. 2017, 97, 5139-5145. [CrossRef]

12. Alvarez, J.M.; Pasian, C.; Lal, R.; Lopez, R.; Fernandez, M. Vermicompost and Biochar as growing media replacement for ornamental plant production. J. Appl. Hortic. 2017, 19, 205-214. [CrossRef]

13. Alvarez, J.M.; Pasian, C.; Lal, R.; Lopez-Nuñez, R.; Fernández, M. A biotic strategy to sequester carbon in the ornamental containerized bedding plant production: A review. Span. J. Agric. Res. 2018, 16, 4. [CrossRef]

14. Zulfiqar, F.; Younis, A.; Chen, J. Biochar or Biochar-Compost Amendment to a Peat-Based Substrate Improves Growth of Syngonium podophyllum. Agronomy 2019, 9, 460. [CrossRef] 
15. Blok, C.; Van Der Salm, C.; Hofland-Zijlstra, J.; Streminska, M.; Eveleens, B.; Regelink, I.; Fryda, L.; Visser, R. Biochar for horticultural rooting media improvement: Evaluation of Biochar from gasification and slow pyrolysis. Agronomy 2017, 7, 6. [CrossRef]

16. Gu, M.; Li, Q.; Steele, P.H.; Niu, G.; Yu, F. Growth of "Fireworks" gomphrena grown in substrates amended with biochar. J. Food Agric. Environ. 2013, 11, 819-821.

17. Fryda, L.; Visser, R.; Schmidt, J. Biochar Replaces Peat in Horticulture: Environmental Impact Assessment of Combined Biochar \& Bioenergy Production. Detritus 2019, 5, 132-149.

18. Huang, L.; Gu, M. Effects of biochar on container substrate properties and growth of plants-A review. Horticulturae 2019, 5, 14. [CrossRef]

19. Margenot, A.J.; Griffin, D.E.; Alves, B.S.Q.; Rippner, D.A.; Li, C.; Parikh, S.J. Substitution of peat moss with softwood biochar for soil-free marigold growth. Ind. Crop. Prod. 2018, 112, 160-169. [CrossRef]

20. Guo, Y.; Niu, G.; Starman, T.; Volder, A.; Gu, M. Poinsettia Growth and Development Response to Container Root Substrate with Biochar. Horticulturae 2018, 4, 1. [CrossRef]

21. Steiner, C.; Harttung, T. Biochar as a growing media additive and peat substitute. Solid Earth 2014, 5, 995-999. [CrossRef]

22. Vaughn, S.F.; Kenar, J.A.; Thompson, A.R.; Peterson, S.C. Comparison of biochars derived from wood pellets and pelletized wheat straw as replacements for peat in potting substrates. Ind. Crop. Prod. 2013, 51, 437-443. [CrossRef]

23. Dispenza, V.; De Pasquale, C.; Fascella, G.; Mammano, M.M.; Alonzo, G. Use of biochar as peat substitute for growing substrates of Euphorbia $\times$ lomi potted plants. Span. J. Agric. Res. 2016, 14, 21. [CrossRef]

24. Choi, H.; Son, H.; Kim, C. Predicting financial distress of contractors in the construction industry using ensemble learning. Expert Syst. Appl. 2018, 110, 1-10. [CrossRef]

25. Shackley, S.; Hammond, J.; Gaunt, J.; Ibarrola, R. The feasibility and costs of biochar deployment in the UK. Carbon Manag. 2011, 2, 335-356. [CrossRef]

26. Gul, S.; Whalen, J.K. Biochemical cycling of nitrogen and phosphorus in biochar-amended soils. Soil Biol. Biochem. 2016, 103, 1-15. [CrossRef]

27. Altland, J.E.; Locke, J.C. Biochar affects macronutrient leaching from a soilless substrate. HortScience 2012, 47, 1136-1140. [CrossRef]

28. Viger, M.; Hancock, R.D.; Miglietta, F.; Taylor, G. More plant growth but less plant defence? First global gene expression data for plants grown in soil amended with biochar. GCB Bioenergy 2015, 7, 658-672. [CrossRef]

29. French, E.; Iyer-Pascuzzi, A.S. A role for the gibberellin pathway in biochar-mediated growth promotion. Sci. Rep. 2018, 8, 1-10. [CrossRef]

30. Prendergast-Miller, M.T.; Duvall, M.; Sohi, S.P. Biochar-root interactions are mediated by biochar nutrient content and impacts on soil nutrient availability. Eur. J. Soil Sci. 2014, 65, 173-185. [CrossRef]

31. Abiven, S.; Hund, A.; Martinsen, V.; Cornelissen, G. Biochar amendment increases maize root surface areas and branching: A shovelomics study in Zambia. Plant Soil 2015, 395, 45-55. [CrossRef]

32. Hilioti, Z.; Michailof, C.M.; Valasiadis, D.; Iliopoulou, E.F.; Koidou, V.; Lappas, A.A. Characterization of castor plant-derived biochars and their effects as soil amendments on seedlings. Biomass Bioenergy 2017, 105, 96-106. [CrossRef]

33. Bachmann, R.T.; Adawiyah, S.; Krishnan, T.; Khoo, B.; Sian, T.S.; Richards, T. Partial substitution of peat moss with biochar for sustainable cultivation of Durio zibethinus L. in nurseries. Arab. J. Geosci. 2018, 11, 426. [CrossRef]

34. Chrysargyris, A.; Prasad, M.; Kavanagh, A.; Tzortzakis, N. Biochar type and ratio as a peat additive/partial peat replacement in growing media for cabbage seedling production. Agronomy 2019, 9, 693. [CrossRef]

35. Kloss, S.; Zehetner, F.; Dellantonio, A.; Hamid, R.; Ottner, F.; Liedtke, V.; Schwanninger, M.; Gerzabek, M.H.M.H.; Soja, G. Characterization of Slow Pyrolysis Biochars: Effects of Feedstocks and Pyrolysis Temperature on Biochar Properties. J. Environ. Qual. 2012, 41, 990-1000. [CrossRef]

36. Yu, P.; Li, Q.; Huang, L.; Niu, G.; Gu, M. Mixed hardwood and sugarcane bagasse biochar as potting mix components for container tomato and basil seedling production. Appl. Sci. 2019, 9, 4713. [CrossRef]

37. Judd, L.A.; Jackson, B.E.; Fonteno, W.C. Advancements in root growth measurement technologies and observation capabilities for container-grown plants. Plants 2015, 4, 369-392. [CrossRef] 
38. Chrysargyris, A.; Antoniou, O.; Athinodorou, F.; Vassiliou, R.; Papadaki, A.; Tzortzakis, N. Deployment of olive-stone waste as a substitute growing medium component for Brassica seedling production in nurseries. Environ. Sci. Pollut. Res. 2019, 26, 35461-35472. [CrossRef]

39. Chrysargyris, A.; Stavrinides, M.; Moustakas, K.; Tzortzakis, N. Utilization of paper waste as growing media for potted ornamental plants. Clean Technol. Environ. Policy 2019, 21, 1937-1948. [CrossRef]

40. Busch, D.; Stark, A.; Kammann, C.I.; Glaser, B. Genotoxic and phytotoxic risk assessment of fresh and treated hydrochar from hydrothermal carbonization compared to biochar from pyrolysis. Ecotoxicol. Environ. Saf. 2013, 97, 59-66. [CrossRef]

41. Liao, N.; Li, Q.; Zhang, W.; Zhou, G.; Ma, L.; Min, W.; Ye, J.; Hou, Z. Effects of biochar on soil microbial community composition and activity in drip-irrigated desert soil. Eur. J. Soil Biol. 2016, 72, 27-34. [CrossRef]

42. Gomez, J.D.; Denef, K.; Stewart, C.E.; Zheng, J.; Cotrufo, M.F. Biochar addition rate influences soil microbial abundance and activity in temperate soils. Eur. J. Soil Sci. 2014, 65, 28-39. [CrossRef]

43. Ameloot, N.; Sleutel, S.; Case, S.D.C.; Alberti, G.; McNamara, N.P.; Zavalloni, C.; Vervisch, B.; delle Vedove, G.; De Neve, S. C mineralization and microbial activity in four biochar field experiments several years after incorporation. Soil Biol. Biochem. 2014, 78, 195-203. [CrossRef]

44. Gorovtsov, A.V.; Minkina, T.M.; Mandzhieva, S.S.; Perelomov, L.V.; Soja, G.; Zamulina, I.V.; Rajput, V.D.; Sushkova, S.N.; Mohan, D.; Yao, J. The mechanisms of biochar interactions with microorganisms in soil. Environ. Geochem. Health 2019, 42, 2495-2518. [CrossRef]

45. EN 13037-2002, 2002 Soil Improvers and Growing Media-Determination of $\mathrm{pH}$.

46. EN 13038-2002, 2002 Soil Improvers and Growing Media-Determination of Electrical Conductivity.

47. EN 13651-2002, 2002. Soil Improvers and Growing Media-Extraction of Calcium Chloride/DTPA (CAT).

48. Sinha, P.; Datar, A.; Jeong, C.; Deng, X.; Chung, Y.G.; Lin, L.C. Surface Area Determination of Porous Materials Using the Brunauer-Emmett-Teller (BET) Method: Limitations and Improvements. J. Phys. Chem. C 2019, 123, 20195-20209. [CrossRef]

49. Kelepesi, S.; Tzortzakis, N.G. Olive mill wastesA growing medium component for seedling and crop production of lettuce and chicory. Int. J. Veg. Sci. 2009, 15, 325-339. [CrossRef]

50. Chrysargyris, A.; Panayiotou, C.; Tzortzakis, N. Nitrogen and phosphorus levels affected plant growth, essential oil composition and antioxidant status of lavender plant (Lavandula angustifolia Mill.). Ind. Crop. Prod. 2016, 83, 577-586. [CrossRef]

51. Tzortzakis, N.G.; Tzanakaki, K.; Economakis, C.D.C.D. Effect of origanum oil and vinegar on the maintenance of postharvest quality of tomato. Food Nutr. Sci. 2011, 2, 974-982. [CrossRef]

52. Chrysargyris, A.; Xylia, P.; Botsaris, G.; Tzortzakis, N. Antioxidant and antibacterial activities, mineral and essential oil composition of spearmint (Mentha spicata L.) affected by the potassium levels. Ind. Crop. Prod. 2017, 103, 202-212. [CrossRef]

53. Loreto, F.; Velikova, V. Isoprene produced by leaves protects the photosynthetic apparatus against ozone damage, quenches ozone products, and reduces lipid peroxidation of cellular membranes. Plant Physiol. 2001, 127, 1781-1787. [CrossRef]

54. De Azevedo Neto, A.D.; Prisco, J.T.; Enéas-Filho, J.; De Abreu, C.E.B.; Gomes-Filho, E. Effect of salt stress on antioxidative enzymes and lipid peroxidation in leaves and roots of salt-tolerant and salt-sensitive maize genotypes. Environ. Exp. Bot. 2006, 56, 87-94. [CrossRef]

55. Fornes, F.; Belda, R.M.; Fernández de Córdova, P.; Cebolla-Cornejo, J. Assessment of biochar and hydrochar as minor to major constituents of growing media for containerized tomato production. J. Sci. Food Agric. 2017, 97, 3675-3684. [CrossRef] [PubMed]

56. Shackley, S.; Ruysschaert, G.; Zwart, K.; Glaser, B. Biochar in European Soils and Agriculture: Science and Practice; Routledge: London, UK, 2016.

57. Ronga, D.; Francia, E.; Allesina, G.; Pedrazzi, S.; Zaccardelli, M.; Pane, C.; Tava, A.; Bignami, C. Valorization of Vineyard By-Products to Obtain Composted Digestate and Biochar Suitable for Nursery Grapevine (Vitis vinifera L.) Production. Agronomy 2019, 9, 420. [CrossRef]

58. Dunlop, S.J.; Arbestain, M.C.; Bishop, P.A.; Wargent, J.J. Closing the loop: Use of biochar produced from tomato crop green waste as a substrate for soilless, hydroponic tomato production. HortScience 2015, 50, 1572-1581. [CrossRef]

59. Nair, A.; Carpenter, B. Biochar rate and transplant tray cell number have implications on pepper growth during transplant production. Horttechnology 2016, 26, 713-719. [CrossRef] 
60. Sun, L.; Li, L.; Chen, Z.; Wang, J.; Xiong, Z. Combined effects of nitrogen deposition and biochar application on emissions of $\mathrm{N}_{2} \mathrm{O}, \mathrm{CO}_{2}$ and $\mathrm{NH}_{3}$ from agricultural and forest soils. Soil Sci. Plant Nutr. 2014, 60, 254-265. [CrossRef]

61. Bedussi, F.; Zaccheo, P.; Crippa, L. Pattern of pore water nutrients in planted and non-planted soilless substrates as affected by the addition of biochars from wood gasification. Biol. Fertil. Soils 2015, 51, 625-635. [CrossRef]

62. Prasad, M.; Chrysargyris, A.; McDaniel, N.; Kavanagh, A.; Gruda, N.S.; Tzortzakis, N. Plant nutrient availability and $\mathrm{pH}$ of biochars and their fractions, with the possible use as a component in a growing media. Agronomy 2020, 10, 10. [CrossRef]

63. Bunt, A. Media and Mixes for Container-Grown Plants: A Manual on the Preparation and Use of Growing Media for Pot Plants, 1st ed.; Unwin Hyman Ltd.: London, UK, 1988.

64. Reyes-Torres, M.; Oviedo-Ocaña, E.R.; Dominguez, I.; Komilis, D.; Sánchez, A. A systematic review on the composting of green waste: Feedstock quality and optimization strategies. Waste Manag. 2018, 77, 486-499. [CrossRef]

65. Wang, S.; Gao, B.; Zimmerman, A.R.; Li, Y.; Ma, L.; Harris, W.G.; Migliaccio, K.W. Physicochemical and sorptive properties of biochars derived from woody and herbaceous biomass. Chemosphere 2015, 134, $257-262$. [CrossRef]

66. Altland, J.E.; Locke, J.C. Effect of biochar type on macronutrient retention and release from soilless substrate. HortScience 2013, 48, 1397-1402. [CrossRef]

67. Liang, B.; Lehmann, J.; Solomon, D.; Kinyangi, J.; Grossman, J.; O’Neill, B.; Skjemstad, J.O.; Thies, J.; Luizão, F.J.; Petersen, J.; et al. Black Carbon Increases Cation Exchange Capacity in Soils. Soil Sci. Soc. Am. J. 2006, 70, 1719-1730. [CrossRef]

68. Maroušek, J.; Kolář, L.; Vochozka, M.; Stehel, V.; Maroušková, A. Biochar reduces nitrate level in red beet. Environ. Sci. Pollut. Res. 2018, 25, 18200-18203. [CrossRef] [PubMed]

69. Takaya, C.A.; Fletcher, L.A.; Singh, S.; Anyikude, K.U.; Ross, A.B. Phosphate and ammonium sorption capacity of biochar and hydrochar from different wastes. Chemosphere 2016, 145, 518-527. [CrossRef] [PubMed]

70. Chintala, R.; Mollinedo, J.; Schumacher, T.E.; Papiernik, S.K.; Malo, D.D.; Clay, D.E.; Kumar, S.; Gulbrandson, D.W. Nitrate sorption and desorption in biochars from fast pyrolysis. Microporous Mesoporous Mater. 2013, 179, 250-257. [CrossRef]

71. Kammann, C.I.; Schmidt, H.P.; Messerschmidt, N.; Linsel, S.; Steffens, D.; Müller, C.; Koyro, H.W.; Conte, P.; Stephen, J. Plant growth improvement mediated by nitrate capture in co-composted biochar. Sci. Rep. 2015, 5, 11080. [CrossRef]

72. Yan, M. Seed priming stimulate germination and early seedling growth of Chinese cabbage under drought stress. S. Afr. J. Bot. 2015, 99, 88-92. [CrossRef]

73. Méndez, A.; Cárdenas-Aguiar, E.; Paz-Ferreiro, J.; Plaza, C.; Gascó, G. The effect of sewage sludge biochar on peat-based growing media. Biol. Agric. Hortic. 2017, 33, 40-51. [CrossRef]

74. Graber, E.R.; Harel, Y.M.; Kolton, M.; Cytryn, E.; Silber, A.; David, D.R.; Tsechansky, L.; Borenshtein, M.; Elad, Y. Biochar impact on development and productivity of pepper and tomato grown in fertigated soilless media. Plant Soil 2010, 337, 481-496. [CrossRef]

75. Kim, H.S.; Kim, K.R.; Yang, J.E.; Ok, Y.S.; Kim, W., Il; Kunhikrishnan, A.; Kim, K.H. Amelioration of Horticultural Growing Media Properties Through Rice Hull Biochar Incorporation. Waste Biomass Valorization 2017, 8, 483-492. [CrossRef]

76. Chrysargyris, A.; Nikolaidou, E.; Stamatakis, A.; Tzortzakis, N. Vegetative, physiological, nutritional and antioxidant behaivor of spearmint (Mentha spicata L.) in response to differnet nitrogen supply in hydroponics. J. Appl. Res. Med. Aroma. 2017, 6, 52-61.

77. Gupta, D.D.; Palma, J.M.; Corpas, F.J. Reactive Oxygen Species and Oxidative Damage in Plants under Stress; Springer: Berlin/Heidelberg, Germany, 2015; ISBN 9783319204208.

78. Savvas, D.; Gruda, N. Application of soilless culture technologies in the modern greenhouse industry-A review. Eur. J. Hortic. Sci. 2018, 83, 280-293. [CrossRef] 